\title{
Den tidligere umatrikulerte grunnen i Finnmark: Jordfellesskap fremfor statlig eiendom?
}

Øyvind Ravna, Professor dr. juris, Det juridiske fakultet, UiT Norges arktiske universitet og professor II ved Samisk Høyskole, Kautokeino

Den tidligere umatrikulerte grunnen i Finnmark har lenge vært betraktet som statens eiendom, noe Samerettsutvalgets rettsgruppe stadfestet i 1993 og som senere er lagt til grunn av Høyesterett i Stjernøya- og Nesseby-dommen i hhv. 2016 og 2018. Denne eiendomsretten var tydeliggjort $\mathrm{i}$ en resolusjon fra 1775, som angivelig åpnet for utvisning av jord til oppsittere $\mathrm{i}$ Finnmark. I dette arbeidet synliggjøres det at resolusjonen initierte utskifting av jordfellesskap - framfor utvisning av statens jord. Dette viser også at bygde- eller siidajorda; engslettene og den nære utmarka, lå i jordsameie og ikke var statlig eiendom. Statens tidligere eiendomsrett til den umatrikulerte grunnen har dannet et grunnlag for Finnmarkseiendommens rett $\mathrm{i}$ dag, noe som betyr at artikkelen har betydelig aktualitet for den pågående rettskartleggingen i Finnmark.

Nøkkelord: Finnmark, «Statens grunn i Finnmark», «jordutvisning», jorddeling, utskifting, jordskifte, jordfellesskap, samerett

\section{Innholdsfortegnelse}

\section{INNLEDNING 2}
1.1. TEMA OG PROBLEMSTILLING 2
1.2. METODE OG KILDER 3
1.3. GJELDENDE OPPFATNING OM RETTEN TIL JORDEN I FINNMARK PA 1700-TALLET4
1.4. BEGREPENE JORDFELLESSKAP, UTSKIFTNING, EIENDOM OG ALLMENNING 6

\section{1775-RESOLUSJONEN: FORARBEIDER, FORMAL OG BESTEMMELSER 8}
2.1. BETYDNINGEN AV DATIDENS DANSK-NORSKE JORDBRUKSPOLITIKK 8
2.2. AMTMANN FIELDSTEDS PROMEMORIA OM JORDINNDELING 9
2.3. KGL. RESOLUTION ANG. JORDBRUGETS INDDELING TIL VISSE BOPLADSER I FINMARKEN FEIL! BOKMERKE ER IKKE DEFINERT.
2.4. RESOLUSJONENS SKJØTEFORMULAR OG LANDMÅLERINSTRUKS 14

\section{SAMTIDIGE BESKRIVELSER I LITTERATUR OG I INNBERETNING FRA AMTENE}

3.1. BINGS BESKRIVELSE AV KONGERIKET NORGE - OG JORDDELINGEN I FINMARKEN 16

3.2. RATHKES BERETNING OM UDSKIFTNING OG KRAFTS BERETNING OM FINNMARK SOM SAMEIE

3.3. OVERSIKT OVER JORDFELLESSKAP OG UTSKIFTINGER I TRONDHIEMS STIFT PER 180318

3.4. HVORFOR UTSKIFTING I VEST-MEN IKKE I ØST-FINNMARK? 19

3.5. OM STATENS ALLMENNINGER I FINMARKEN, JORD UTEN KGL. SKJØTE OG 1863-LOVEN 20

\section{DRøFTING 22}

4.1. VURDERING AV NOEN SENTRALE FORSKNINGS- OG UTREDNINGSARBEIDER OG DERES BETYDNING 22 4.1.1. Tønnesen og retten til jorden i Finnmark 22

4.1.2. Samerettsutvalgets rettsgruppes utredning av retten til land og vann i Finnmark 24 4.1.3. Niemis utredning om lokalbefolkningen og staten og Høyesteretts dom i Nessebysaken 25

4.2. JORDFELLESSKAP OG UTSKIFTING FRAMFOR STATENS GRUNN OG JORDUTVISNING 26

4.2.1. Betydningen av «læren om statens grunn» 26

4.2.2. 1775-Resolusjonen som en utskiftningslov 28

4.2.3. Dispositive utsagn 30

\section{AVSLUTNING 31}

REFERANSER 33 


\section{Innledning 1}

\subsection{Tema og problemstilling}

Finnmarks retts- og eiendomshistorie skiller seg fra det øvrige Norge. Skillet ligger ikke bare i at Finnmark langt senere enn resten av landet ble en del av Norge; det ligger også i at den rådende oppfatningen over lange perioder har vært at den norske stat ikke bare var utøvende myndighet $\mathrm{i}$ Finnmark i statsrettslig forstand, men også eier av jorda der i privatrettslig forstand. Betegnende er forarbeidene til vår forrige «finnmarkslov», jordsalgsloven av 1965, hvor det ble uttalt at all jord og grunn i det egentlige Finnmark er betraktet som statens eiendom «[s]å langt tilbake som den norske soge vet å berette». ${ }^{2}$ Videre het det at i motsetning til sør i landet, «hvor privat eiendomsrett til jord alt i sagatiden var fast instituert, fantes i Finnmark ingen private jordeiendommer». ${ }^{3}$ Slike eiendommer oppsto først i 1775 gjennom en resolusjon som «bestemte at jord - boplasser - kunne utvises til full eiendom. Utvisningen var gratis. Fra denne tid oppstår privat eiendomsrett til jord i Finnmark».

For en som ikke kjenner eiendomshistorien og de juridiske betraktningene omkring denne, må disse fremstillingene fortone seg som underlige. Hvordan kan det ha seg at folk som har hatt sine bosteder, engsletter og båtlandingsplasser gjennom hundrevis av år, ikke har hatt eiendomsrett til disse? Ikke en gang der de hadde sine jordgammer eller -fjøs stående, skal de ha hatt eiendomsrett. Det søkes besvart i det følgende.

Sentralt i denne historien står den nevnte resolusjonen, ofte omtalt som $\mathrm{Kgl}$. Resolution av 27. mai 1775 angaande Jorddelingen i Finmarken samt Bopladses Udvisning og Skyldloegning sammesteds, ${ }^{4}$ eller i kortform jordutvisningsresolusjonen. Den er i ettertid forstått som en kongelig ordre om å utvise kongens jord til oppsittere i Finnmark, og dermed som grunnlaget [222] for privat eiendomsrett i fylket. Som dokumentasjon på statens eierposisjon har resolusjonen blitt tungt vektlagt, ikke bare i arbeidet med jordsalgsloven av 1965, men også da Samerettsutvalgets rettsgruppe kom til at staten var eier av den tidligere umatrikulerte jorda i Finnmark. ${ }^{5}$

\footnotetext{
*Viser til sidetall i den publiserte artikkelen i Tidsskrift for Rettsvitenskap, vol. 133, 2-3/2020

${ }^{1}$ Takk til professor dr.juris Jens Edvin A. Skoghøy, dr.philos. Steinar Pedersen og en anonym fagfelle for gjennomlesning og nyttige merknader.

2 Innstilling om lov og forskrifter om Statens umatrikulerte grunn i Finnmark fylke, 1962 s. 5 . Med det egentlige Finnmark menes amtet slik det var før 1787 (og fra 1866-2020), altså uten Troms fylke, se Geir Thorsnæs, "Finmarkens amt», Store norske leksikon, 2017, https://snl.no/Finmarkens amt (23.02.2020).

${ }^{3}$ Innstilling om lov og forskrifter om Statens umatrikulerte grunn i Finnmark fylke, 1962 s. 7.

${ }^{4}$ Se lovdata, https://lovdata.no/dokument/NL/lov/1775-05-27 (23.02.2020) (forkortet 1775-resolusjonen).

${ }^{5}$ NOU 1993: 34 Rett til og forvaltning av land og vann i Finnmark s. 88-90, jf. s. 266. Se også

Gudmund Sandvik, "Statens grunn i Finnmark. Et historisk perspektiv», vedlegg til i NOU 1993: $34 \mathrm{~s}$.
} 
Selv om få i dag vil mene at staten har eid jorda i Finnmark «så lenge soga vet å berette», rett og slett fordi Finnmark i sagatiden ikke var en del av Norge, har resolusjonen likevel en sentral plass i Finnmarks retts- og eiendomshistorie. Det har gjort det vanskelig å argumentere for at eiendommer kan ha oppstått uavhengig av statens disposisjoner, slik de har gjort andre steder i landet, og dermed at det kan ha vært andre eiere til jord i Finnmark enn staten i eldre tid. Selv om det etter hvert er stilt spørsmål ved statens tidligere rett til jorda i Finnmark, er resolusjonen tillagt betydelig vekt som grunnlag for å avskjære rettskrav fra bygdefolk i Finnmark under den pågående rettskartleggingen i Finnmark. ${ }^{6}$

I det følgende drøftes alternative måter å vurdere resolusjonen på. Det spørres bl.a. om det i dens uttalte målsetting om å «forbedre jordbruket», kan ha ligget en plan om å oppløse jordfellesskap, utviklet i de eldste bygdesamfunnene eller samiske siidaene langs Finnmarksfjordene, framfor å utvise jord fra staten til bygdefolket. Målet kan ha vært forankret i et ønske om at oppsitterne fikk sin andel av fellesskapet lagt ut til eneeie ved utskifting. Ved å få jorda i eneeie, kunne eierne dyrke den, gjerde den inn og høste den hver for seg, og dermed sikre vinterfôr til buskapen. Dette framfor å flytte mellom sommer- og vinterboplasser på stadig leting etter beite, noe som den gang betegnet husdyrholdet langs Finnmarksfjordene.

I dette arbeidet drøftes således formålet og funksjonen til 1775-resolusjonen for slik å belyse grunneierforholdene i Finnmark. Problemstillingen er dermed å undersøke datidens eiendomsforhold, herunder om bildet av [223] statens posisjon som grunneier kan nyanseres og om det finnes en annen eiendomshistorie for Finnmark enn den som lenge er fortalt.

Betydningen av statens tidligere posisjoner under den pågående rettskartleggingen i Finnmark gjør at en slik rettshistorisk undersøkelse kan ha vesentlig relevans for gjeldende rett.

\subsection{Metode og kilder}

Innledningsvis presenteres den oppfatning av rettssituasjonen omkring $1775 \mathrm{som}$ i dag har bredest støtte i fagmiljøene, samt noen sentrale begreper. Som et bakteppe for drøftingene undersøkes deretter den samtidige (danske) landbrukspolitiske utviklingen og den danske utskiftingslovgivingen i siste halvdel av 1700-tallet, før resolusjonens forarbeider, fortale, tekst og tilhørende instruks gjennomgås. Videre gjennomgås samtidige dokumenter og litteratur egnet til å belyse resolusjonens utkomme og utviklingen utover 1800-tallet.

334-380 (s. 363) og Gudmund Sandvik, "Om oppfatningar av retten til og bruken av land og vatn $i$ Finnmark fram mot slutten av 1960-åra», vedlegg til NOU 1997: 4 Naturgrunnlaget for samisk kultur s. 578-607 (s. 586-587).

${ }^{6}$ Dette ble tydeliggjort av Høyesterett i HR-2018-456-P (Nesseby), særlig i avsnitt 136 og 138. Se forøvrig Finnmarkskommisjonen, bl.a. Rapport felt 2 Nesseby, 2012 s. 19 og Rapport felt 6 Varanger vest, 2015 s. 24. Se også Rapport felt 4 Karasjok, 2019 s. 36 (selv om kommisjonen her legger langt mindre vekt på statens disposisjoner enn i forutgående rapporter). 
Med bakgrunn i dette drøftes de eldre kildene opp mot den historiografiske og rettvitenskaplige forskningen som har vært rådende helt fram til i dag med henblikk på å belyse retts- og eiendomshistorien i Finnmark. Det undersøkes særlig om disse kildene kan kaste nytt lys over eiendomsforholdene i 1775, og om resolusjonen kan ha initiert noe annet enn jordutvisningen fra staten til folk i Finnmark. Metodisk sett hensyntas det at eiendomsbegrepet hadde et noe annet innhold i den dansknorske enevoldstiden enn i dag. ${ }^{7}$

De eldre kildene som er nyttet, framgår av kapitlene 2 og 3. Blant disse finner vi arbeider av sorenskriver Hans Paus og amtmann Torkil Fieldsted, andre originalkilder fra tidsrommet, innbefattet den nevnte danske lovgivningen og samtidig litteratur.

Som i all forskning er det viktig å ta utgangspunkt i gjeldende kunnskapsstatus. For dette arbeidet er forskningen til Sverre Tønnesen fortsatt svært viktig. ${ }^{8}$ Det er også arbeidet til Samerettsutvalgets rettsgruppe, hvor det ble tatt stilling til eierskapet til den tidligere umatrikulerte grunnen i Finnmark. ${ }^{9}$ Videre er arbeider av Steinar Pedersen, Kirsti Strøm Bull, Jon [224] Gauslaa og Einar Niemi av interesse. ${ }^{10}$ Nevnes må også egne arbeider. ${ }^{11}$ Det seneste bidraget av aktualitet er Finnmarkskommisjonens utredning for Karasjok fra desember 2019. ${ }^{12}$

\subsection{Gjeldende oppfatning om retten til jorden i Finnmark på 1700-tallet}

Gjennom de to siste hundreårene har mange akademikere drøftet rettsforholdene i Finnmark. Blant disse er Fr. Brandt, professor i rettsvitenskap ved Det Kgl. Frederiks Universitet i Christiania. Han skriver i 1867 at «[d]et egentlige Finmarken har lige fra den ældste Tid været betragtet som den norske Stats Ejendom». Og videre at «[f]ørst langt ned i den historiske Tid er dette Distrikt blevet bebygget af Indvandrede; men disse ansaaes ikke som Ejere af Grunden [...]». ${ }^{13}$ Dette skulle skape en skole for kommende akademikere.

Av andre betydningsfulle rettsvitere på området nevnes Knut Spilling, sorenskriver og jordkommisær i Finnmark (1910-1922) og Ola Juvkam, professor i utskiftning ved Norges

\footnotetext{
${ }^{7}$ Dette redegjøres det for i punkt 1.4 nedenfor.

${ }^{8}$ Sverre Tønnesen, Retten til jorden i Finnmark. Rettsreglene om den såkalte «Statens umatrikulerte grunn» - en undersøkelse med særlig sikte på samenes rettigheter, Bergen 1972.

${ }_{9}^{9}$ NOU 1993: 34 Rett til og forvaltning av land og vann i Finnmark.

10 Steinar Pedersen, «Fra bruk av naturgodene etter samisk sedvaner til forbud mot salg til ikkenorsktalende», NOU 2001: 34 Samiske sedvaner og rettsoppfatninger s. 291-381, Kirsti Strøm Bull, Jordsalgslovgivning. En rettshistorisk gjennomgang lovgjennomgang av jordsalgslovgivningen $i$ Finnmark i perioden 1775-1965, 2014 (upubl.), Jon Gauslaa, «Eigedomshistoria i Finnmark», Hans Sevatdal, ved Per Kåre Sky og Erling Berge (red.), Eigedomshistorie. Hovudliner i norsk eigedomshistorie frå 1600-talet fram mot nåtida, Oslo 2017 s. 302-320 og Einar Niemi, Lokalbefolkningen og staten i Nesseby. Et utsyn fra 1700-tallet, 2017 (upubl.).

${ }^{11}$ Øyvind Ravna, "Jordutvisning og jordordning i Finnmark i et historisk perspektiv» Kart og plan, 1999

s. 132-145 og «Nye bidrag til eiendomshistorien i Finnmark», Heimen, 2017 s. 6-27. DOI:

10.18261/ISSN.1894-3195-2017-01-02

${ }^{12}$ Finnmarkskommisjonen, Rapport felt 4 Karasjok, bind 1, 2019.

${ }^{13}$ Fr. Brandt, Tingsretten fremstillet efter den norske Lovgivning, Christiania 1867 s. 194.
} 
Landbrukshøgskole. Synspunktene de fremmet i første halvdel av 1900-tallet, har imidlertid liten støtte i dag, og jeg finner derfor ikke grunn til å drøfte disse nærmere. ${ }^{14}$

Sverre Tønnesen, politijurist og senere professor i rettsvitenskap, er det imidlertid grunn til å gå nærmere innpå. Han er den første som tok til motmæle mot læren om statens grunn i Finnmark. I doktorgradsarbeidet [225] Retten til jorden i Finnmark kommer han til at jorden i Finnmark besto av allmenninger hvor bygdefolk har rettigheter etter alders tids bruk. ${ }^{15}$ Tønnesens betraktninger om rettstilstanden i Finnmark ved inngangen til 1700-tallet har fortsatt bred tilslutning i fagmiljøene. ${ }^{16}$ Han beskriver den slik:

1) Kongen var landsherre, og utøvet en landsherres funksjoner etter loven i Finnmarks kyst- og fjordstrøk. Man kan antakelig anta at han (og sentraladministrasjonen) anså

Finnmarksallmenningen som en vanlig almenning i privatrettslig henseende. Man har antakelig ikke grunnlag for å slutte at den ble ansatt som vanlig krongods. Man kan også dernest antakelig anta at Kongen anså finnmarkingenes rettigheter likeverdige med andre eieres rettigheter i andre almenninger, og at de således ansås berettiget til den bruk de hadde utøvet i alders tid.

2) Finnmarkingene besto av to sterkt forskjellige grupper [nordmenn og samer], som må antas å ha hatt rettsoppfatninger av ulik art på dette området. Enkelte likhetspunkter finnes nok. Begge grupper må antas å ha ment å ha rettighet til bruk i almenningen, og antakelig i den del som tillå deres bygdelag/fiskevær/ sameby [siida]. Men ulik rettshistorie og ulikt næringsgrunnlag har nok også skapt ulikheter, i hvert fall i styrken av rettighetsfølelsen. ${ }^{17}$

Tønnesen skriver samme sted at det også hos nordmennene langs kysten etter hvert grodde frem en forestilling om at bygdelaget hadde rett fremfor andre innen bygdas område, uten at dette har vært særlig fasttømret. De enkelte samegrupper bygget sin rettsoppfatning på gammel samisk sedvane, fortsetter Tønnesen. Sjøsamene som holdt til i fjordstrøkene har antakelig oppfattet seg berettiget til det området samebyen hadde besittet og brukt $\mathrm{i}$ alders tid: «Etter nåtidens mål ville man vel anse dem som eiendomsberettiget til området..> ${ }^{18}$

\footnotetext{
${ }^{14}$ Knut Spilling, «Utskiftingsvæsenet og jordforholdene i Finmarken», Tidsskrift for Det norske Utdskiftningsvæsen, 1920(a) s. 69-82; Av Finmarkens skogret, Bilag til Norsk Retstidende no. 4-6, Kristiania 1920(b); Om jordforhold og odelsrett i Finnmark, Oslo 1937 og O. Juvkam, «Utstykking og skyldsetting i Finnmark», Tidsskrift for Det norske Utskiftingsvesen, 1948 s. 127-141.

${ }^{15}$ Tønnesen (1972) s. 306-308 og 311-312.

${ }^{16}$ Finnmarkskommisjonen (2019) s. 34 og Bull (2014) s. 5, som i stor grad slutter seg til Tønnesens standpunkter. Se også Rt. 1979 s. 492 (Varfjell-Stifjell) (s. 498) og senest HR-2018-456-P (Nesseby) avsnitt 130, 130 og 148.

17 Tønnesen (1972) s. 56-57 (uthevet av Tønnesen).

18 Tønnesen (1972) s. 57.
} 
De gamle sedvanene om rettighetene mellom bygdelagene og mellom samebyene holdt seg ifølge Tønnesen utover på 1700-tallet. Det de imidlertid [326] ikke kunne greie, var å fordele goder blant bygdelagenes medlemmer, [226] noe som var sentralt for det gryende jordbruket, og som ledet til arbeidet med 1775-resolusjonen. ${ }^{19}$ Tønnesen skriver også at manglende bruk av Christian Den Femtis Norske Lov av 1687 (NL) om rydning i allmenning bl.a. kunne tilskrives en antakelse om at «Kongen muligens i eldre tid sto svakere i Finnmarksalmenningen enn i andre kongsalmenninger». ${ }^{20}$

Før vi forlater tiden før 1775, kan det vises til at Gudmund Sandvik skriver at «[s]amane - og siden 1200-talet tilfyttarer ytst på kysten - kan ikkje i det heile ha drege i tvil at dei hadde rett til å ta landområde i bruk og gjera seg nytte av naturgoda der». ${ }^{21}$

\subsection{Begrepene jordfellesskap, utskifting, eiendom og allmenning}

I eldre tid lå ofte jorda i bygdene i jordfellesskap, mens den litt fjernere utmarka kunne være allmenning. Dette var i stor grad tilfellet langs kyst-Norge, fra Vestlandet og nordover. ${ }^{22}$ Med jordfellesskap menes jordsameie. Slikt fellesskap har i stor grad vært gjenstand for utskifting, ${ }^{23}$ noe som betyr at sameiet ble oppløst og delt til teiger til eneeie. I dag er slikt sameie, som oftest omfatter utmark, knyttet til en eiendom i bygda. Før utskiftingene fikk et visst omfang, kunne all jord i bygda, også innmarka, ligge i sameie. Motstykket til «eiendom» ble slik sett jordfellesskap, og ikke, som i dag, offentlig eid grunn. Eiendommer (i eneeie) har dermed oppstått ved utskifting eller deling av jordfellesskapet. For øvrig kan eiendom ha oppstått uavhengig av statlige akter. Om vi ser bort fra statlige salg av allmenninger, har de fleste eiendommer, jordfellesskap så vel som eneeie, en gang i tiden oppstått gjennom originære erverv (landnåm), sedvane, alders tids bruk eller hevd. ${ }^{24}$

[227] Det må også tas med at i den dansk-norske enevoldstiden (i Norge fram til 1814) ${ }^{25}$ var eiendomsretten ennå forankret i tenkning fra middelalderens føydal- eller lensvesen. Dette innebar at retten var delt mellom kongen (eller jorddrotten) som hadde overeiendomsrett (dominium directum), og brukeren, som dyrket jorda, og som hadde undereiendomsrett (dominium utile).

\footnotetext{
19 Tønnesen (1972) s. 66.

${ }^{20}$ Tønnesen (1972) s. 86. Dette er ikke underlig da Indre Finnmark først kom under norsk jurisdiksjon 24 år før 1775-resolusjonen ble vedtatt, og de sørøstligste delene så seint som i 1826.

${ }^{21}$ Sandvik (1997) s. 584.

${ }^{22}$ Mads Langnes, «Det fordervelege jordfellesskapet», Heimen, 2019 s. 279-295, https://doi.org/10.18261/ issn.1894-3195-2019-04-04 er bakgrunnen for jordfellesskapet drøftet. ${ }^{23} \mathrm{Fra}$ lov 22. des. 1950 om jordskifte o.a. betegnet som jordskifte, som etter § 2 omfattet oppløsning av sameie og teigblanding, se også punkt 2.2 nedenfor. Også teigblanding kunne falle inn under begrepet jordfellesskap, gjerne omtalt som ufullkomment jordfellesskap.

${ }^{24} \mathrm{Fra}$ Island er landnåm velkjent som følge av at folk kom til en ubebodd øy og kunne besette land de kom til hvoretter sagatidens skalder kunne nedtegne det som skjedde. I områder der folk har holdt til atskilling lenger, samtidig som de ikke har hatt skriftspråk eller har vært fast bosatte, er landnåm vanskelig å dokumentere.

${ }^{25}$ Danmarks enevoldstid strekker seg fra 1660 til 1848, se Dag Michalsen, Rett en internasjonal historie, Oslo 2011 s. 242.
} 
Overeiendomsretten (også omtalt som høyhetsrett) hadde et offentligrettslig eller statsrettslig preg, mens undereiereiendomsretten var av privatrettslig art, hvor eierens ytelse til overeieren dels ble betegnet som landskyld og dels som skatt. ${ }^{26}$

I eldre nordisk rett kunne eiendomsretten også være funksjonell, eller «kløyvd», idet det eksempelvis kunne være forskjellige eiere til skog og beite, uten at dette har vesentlig betydning for den videre framstillingen her. ${ }^{27}$

For øvrig nevnes at vern mot inngrep i eiendom ikke var en del av enevoldstidens rett, noe som innebar at kongemakten kunne gripe nokså fritt inn i eiendomsretten og andre rettigheter av privatrettslig karakter. ${ }^{28}$

Med allmenning menes i rettslig sammenheng utmark og fjellområder hvor bygdefolk hadde bestemte bruksrettigheter. ${ }^{29} \mathrm{Om}$ allmenningen ikke var overdratt til en jorddrott (en proprietær), eller lå til kirka, var kongen ansett som eier; angivelig i medhold av overeiendomsretten. ${ }^{30}$ Bygdefolks bruksrettigheter hadde oftest prioritet framfor grunneierretten. Allmenningseieren hadde imidlertid et privilegium; det var retten til landskyld fra bruk som lå i eller ble ryddet i allmenningen, jf. NL 3-127 [228] og 3-12-8. Tradisjonen i Norge var altså at rydningsplassene ble skyldsatt, og at rydningsmannen ble leilending under allmenningseieren. Som vi har sett, har Tønnesen vist at NL ikke ble nyttet til utvisning til boplasser og rydningsjord i Finnmark. Realiteten ble dermed at Finnmark skilte seg fra det øvrige landet ved at det ikke ble utvist rydningsjord i allmenningen, og man fikk heller ikke leilendinger i amtet.

Hvordan eiendommene som sokner til allmenningen har oppstått, kan ha betydning for hvilket rett bygdefolk har til bruk og forvaltning i dag. I Nordland og Troms har allmenningsretten tradisjonelt ikke fulgt med når de tidligere leilendingsbrukene ble solgt til oppsitterne. ${ }^{31}$ Også i Finnmark har staten fratatt bygdefolket allmenningsretten i tiden den anså seg som eier av den umatrikulerte grunnen i fylket. Andre steder i landet har både eiere av tidligere leilendingsbruk og selveide bruk allmenningsrett. I samisk sammenheng er den gamle ordningen med finneodel i Nordland og Troms,

\footnotetext{
${ }^{26}$ Brandt (1867) s. 78-79, Herman Scheel, Forelæsninger over norsk Tingsret, Kristiania 1912 s. 145, Gudmund Sandvik, «Europeisk rettshistorie i mellomalderen. Førelesningar», Jussens venner, $1989 \mathrm{~s}$. 201-309 (s. 233) og Jørn Øyrehagen Sunde, «På sporet av det tapte overbygslingsinstituttet», Historisk tidsskrift, 2004 s. 181-205 (s. 190).

${ }^{27}$ Knut Robberstad, «Kløyvd eiendomsrett», Lov og rett, 1963 s. 162-166.

${ }^{28}$ Finnmarkskommisjonen (2019) s. 32 og Håvard Steinsholt, "Oreigning», Hans Sevatdal, v/Per Kåre Sky og Erling Berge (red.), Eigedomshistorie. Hovudliner i norsk eigedomshistorie frå 1600-talet fram mot nåtida, Oslo 2017 s. 379-381.

${ }^{29}$ Tønnesen (1972) s. 11. Det kan også vises til den mye refererte definisjonen i K. Meinich Olsen, Norsk almenningsret, Oslo 1928 s. 220: «Ved almenning forstaar jeg en strækning, hvor et eller flere bygdelag i kraft av loven har bruksret». I rettslig sammenheng nyttes ikke begrepet med siktet til et område åpent for allmenn ressurshøsting, slik nyttet Garrett Hardin «The Tragedy of the Commons», Science, 1968 s. 1243-1248.

${ }^{30}$ Asm. Schiefloe, Hovedlinjer I Norsk almenningsrett, Os/o 1955 s. 122-137.

${ }^{31}$ Rt. 2001 s. 1229 (Svartskogen) er i så måte et unntak, hvor Høyesterett fant at etterkommerne etter de tidl. leilendingene ikke bare hadde sin allmenningsrett $i$ behold, men også eide allmenningen.
} 
som ikke lenger eksisterer, et eksempel på det. ${ }^{32}$ I Nordland kan også såkalte bufinner som ikke svarte landskyld, ha vært selveiere med allmenningsrett. ${ }^{33}$ Det må også nevnes at det ofte var tilfeldigheter som avgjorde om en utmarksstrekning ble til allmenning eller jordfellesskap. ${ }^{34}$

Om eiendommene i Finnmark har opprinnelse i jordfellesskap, og ikke statlig utvisning, har således ikke bare hatt betydning for eiendomsretten til den nærliggende utmarka, men også for hvilken rett bygdefolk har i allmenningen som en gang kan ha blitt sett på som kongens. Det vil også kunne ha betydning for den pågående rettskartlegginga. [229]

\section{1775-resolusjonen: forarbeider, formål og bestemmelser}

\subsection{Betydningen av datidens dansk-norske jordbrukspolitikk}

På midten av 1700-tallet, parallelt med framveksten av opplysningstidens idealer, fikk myndighetene i Danmark-Norge forståelse for jordfellesskapets hindring for utviklingen av jordbruket. Det må antas at dette også påvirket jordbrukspolitikken enevoldskongen førte overfor Norge, også helt nord i landet. Derfor er det naturlig å se på denne utviklingen.

I 1757 ble det nedsatt en kommisjon som skulle forberede en lov om oppløsning av jordfellesskap i Danmark, og i årene 1758-1761 kom det flere forordninger om utskifting av allmenninger. ${ }^{35}$ Jordfellesskapet ble etter hvert sett på som den største hindringen for et mer effektivt jordbruk da det krevde et omfattende, koordinert samarbeid mellom brukerne. Arbeidsoperasjoner måtte skje samtidig, avling måtte deles eller arealer brukes på årviss omgang, samtidig som husdyr måtte voktes nøye for at de ikke skulle beite ned vinterfôret. I 1769 kom den første forordningen om utskifting til eiendom. I medhold av den kunne enhver jorddrott eller selveier, på egen bekostning forlange sin jord utskiftet. I 1776 ble det åpnet for mer omfattende utskifting, hvor alle berørte måtte delta i kostnadene ved den.

Fem år senere, i 1781, ble en fullstendig lov om utskifting vedtatt for Danmark. ${ }^{36}$ I den var det bestemt at når én loddeier forlangte utskiftning av sin jord, skulle landsbyens jorder oppmåles og fordeles, hvor alle loddeiere var pliktige til å delta i grøftings- og gjerdearbeid m.m. Utskiftingen i

\footnotetext{
32 Lars Ivar Hansen og Bjørnar Olsen, Samenes historie fram til 1750, Oslo 2004 s. 298-302.

${ }^{33}$ Øyvind Ravna, "Utmarkskommisjonen for Nordland og Troms og de samiske interessene», NOU 2007: 14 Samisk naturbruk og rettssituasjon fra Hedmark til Troms s. 607-726 (s. 636-637).

${ }^{34}$ Geir Stenseth, Almenningens janusansikt. En sammenlignende rettslig analyse av almennings- og sameieforhold i norsk utmark, Oslo 2005.

${ }^{35}$ Paul Borgedal, «Jordeiendommenes historie i Norge» i Torleif Grendahl (red.), Jordskifteverket gjennom 100 år 1859-1958, Oslo 1959 s. 135-166 (s. 146). Selv om utskifting hadde tradisjoner tilbake til middelalderen, ble det nå et annet fokus på det som virkemiddel til å forbedre jordbruket, jf. Borgedal (1959) s. 146-147.

${ }^{36}$ Forordning 23 April 1781 om Jord-Fælledsskabets Ophævelse med flere foranstaltninger til Landvæsenets Forbedring i Danmark, se Jacob Henric Schou, Chronologisk Register over de Kongelige Forordninger og Aabne Breve, som fra Aar 1670 af ere udkomne, VIII Deel, fra 1781 til 1784, Kiøbenhavn 1795 s. 96-133.
} 
Danmark økte i omfang, og i 1792 regner man med at om lag 10 prosent av jorda i Danmark var utskiftet. I en innstilling samme år ble det vist til at av alle de ordninger som hadde som hensikt å forbedre bondestandens kår, «fører ingen hurtigere og vissere til det rigtige Maal end Udskiftningen av Fællesskab». ${ }^{37}[230]$ Utskiftingene bidro til at det danske jordbruket omtrent fordoblet sitt årlige utbytte i perioden $1788-1808 .{ }^{38}$

Rentekammeret utarbeidet flere utkast til norske utskiftingslover. ${ }^{39}$ De ble imidlertid ikke vedtatt før Danmark og Norge skilte lag i 1814.

\subsection{Amtmann Fieldsteds promemoria om jordinndeling}

Finnmark var langt unna København. Men også her ønsket myndighetene å bedre kårene for jordbruket. På oppdrag av amtmann Torkil Fieldsted i Finnmark skrev sorenskriver Hans Paus i 1769 en utredning kalt Finmarkens økonomiske tilstand med forslag om dens forbedringer.

Paus' framstilling viser at folket langs fjordene; «Søe-Finnerne», som bodde «ved Søe-Stranden inde udi Fiordene», hadde sine egne jorder (Engeslætter) og her flyttet mellom sine sommer- og vinterboplasser. Paus beskriver også jordsameie; Landets Fcellesskab, som har ført til stort misbruk av jord og skog idet sjøsamene kun nyttet sitt «Sommer-Sæde et aars Tid eller to paa et Stæd [...] som han ruinerer ruunden om sin boelig». ${ }^{40}$ Paus foreslo derfor faste sommer- og vinterbosteder, men klarte ikke å frigjøre seg helt fra fellesskapstanken idet han foreslo at fire familier skulle drive jorda i fellesskap. ${ }^{41}$ Paus beskrev også teigblanding med lange avstander mellom slåttene, noe som innebar at det kunne ta oppimot 14 dager å høste enger som under andre omstendigheter kunne vært slått på noen timer. For å bøte på dette foreslo han makeskifte.

Amtmann Fieldsted oversendte forslaget fra Paus til Rentekammeret med anbefaling om jorddeling. Fieldsted ønsker i motsetning til Paus fullt ut å avvikle jordfelleskapet:

Dersom mand skulde i Finmarken grunde Jordinddelingen og Bopladsers Anlæg paa Grund af Fælledsskab som man paa alle vel indrettede Stæder og Provintzer søge at ophæve, saa Handlede man eftter min ringe Formeening [...] [231] imod den Menneskelige Natur, Fælledskab i Jordbrug

\footnotetext{
${ }^{37}$ Edvard Holm, Danmark-Norges historie fra Den Store Nordiske Krigs Slutning til Rigernes Adskillelse (1790-1814), sjette bind anden del, Kjøbenhavn 1909 s. 418.

${ }^{38}$ Sjur Brækhus og Axel Hæren, Norsk tingsrett, Oslo 1964 s. 24.

${ }^{39}$ O. Juvkam, "Træk fra utskifningsvæsenets historie», Tidsskrift for Det norske Utdskiftningsvæsen, 1917 s. 41-161 (s. 56). Rentekammeret hadde ansvaret for statens finanser i enevoldstiden. Fram til Norge ble skilt fra Danmark hadde Rentekammeret ansvaret for det meste av statens tilsyn og kontakter med lokaladministrasjonene og allmuen i landet, se Rentekammeret, Aarhus universitet, danmarkshistorien.dk (07.12.19).

${ }^{40}$ Hans Paus, Sorenskriver Hans Paus'Indberetning av 1769 om Finmarkens økonomiske tilstand, Vadsø 1908 s. 12-13.

${ }^{41}$ Paus (1769/1908) s. 15-16.
} 
og tilfældige nærings Veje foraarsager intet andet end Dovenskab hos nogle Ueenighed hos andre, og Confusion hos alle. ${ }^{42}$

Det Fieldsted skriver, er svært interessant da det knytter hans vurderinger opp mot den da rådende tanken om å avvikle jordfellesskapet «Paa alle vel indrettede Stæder ...». Dermed kan det også antas at han var inspirert av utviklingen i Danmark, noe som synliggjøres i promemoria av 31. mars 1775, hvor han påpeker nødvendigheten av jordinndeling:

Jeg har til forn ved adskillige Lejligheder [...] andraget, Hvor nødvendig og Nyttig Indrettning det vilde være for Wardøehuus Amt $\left[{ }^{43}\right]$, dersom dets Landgrunde bleve udj vise og bestemte Boepladse inddeele, at saavel enhver Opsiddere kunde fuldkommeligen viide sine Jordbrugs Grændser og være vis paa til Ejendom for sig og sine at beholde [...]. ${ }^{44}$

Et viktig argument for inndelingen var at hver enkelt oppsitter ved å vite grensene for sitt bruk, ville kjenne sin eiendom og kunne dyrke og forbedre den. Jordbruket var videre også viktig for fiskerne, som hadde en usikker tilværelse ved kun å leve av fiskeriet. Fieldsted anfører også at det ville gi rom for «Nye afdeelte Rydningspladse [...] til Nyebyggere». At oppsitterne ikke hadde skjøte på jorda, innebar at den ikke kunne omsettes. Fieldsted mener at dette var grunnen til at få ryddet jord og at allmuen, særlig «Finnerne» fortsatte med den utarmende flyttingen. Han påpeker også at en forordning av 25. april 1702 ikke kunne gi grunnlag for å «udviises visse EjendomsPladse, hvor de med Familie kunde nedsætte sig». ${ }^{45}$

Fieldsted foreslår derfor at det blir utarbeidet en «Plan til en Ordentlig bestemt og vedvarende Jordindeeling udi Wardøehuus Amt». En slik plan [232] vil ikke alene avhjelpe den uorden og uvirksomhet som eksisterte, men også forene jordbruk og fiskeri, «samt og paa en vis og varig Fod, besette Landet med nyttige Beboere». I tillegg til ansettelse av en «duelig og en landkyndig Mands antagelse til denne Forrettning» måtte man lage en plan for «Inddeeelings verket» og «afhjemle de uddeelte Jorder til de nærværende Opsiddere, samt Rydnings Pladser til Nybyggere». ${ }^{46}$ Med andre ord foreslo amtmannen at det skulle utarbeides en delings- eller skifteplan og at daværende oppsittere måtte få oppmålt og tildelt den jorda de hadde tatt $\mathrm{i}$ bruk. I tillegg burde det utmåles rydningsplasser

\footnotetext{
${ }^{42}$ Torkil Fieldsted, Extract Af [...] Sorenskriver Pauses Forslag i Finmarken betreffende, hvorover i Anledning af Jord-Inddeelingen udbedes (Betænkning), i Statsarkivet i Tromsø, Arkivet etter Amtmannen/Fylkesmannen i Finnmark, SATØ/S-1120/1Afe/L1513. Se også Bull (2014) s. 12.

${ }^{43}$ Vardøhus amt ble i 1787 sammenføyd med Tromsø og Senjen fogderi med betegnelsen Finmarkens amt, se Thorsnæs (2017).

${ }^{44}$ Torkil Fieldsted, promemoria 31.03.1775, i Riksarkivet/EA-3111 Rentekammeret, Kammerkanselliet, serie Gfd - Dokumenter til forestillinger, pakke 22 (1772-1775), mappe: N. res. 24/1775 (8/6), 1775 nr. 24, Finnmark vedk. s. 1 (sidetall viser til den håndskrevne originalen).

${ }^{45}$ Fieldsted (1775) s. 7.

${ }^{46}$ Fieldsted (1775) s. 8.
} 
for nybyggere. Og landmåleren måtte «ej alleene [være] kyndig i det almindelige Landvæsen og Jordbrug i Norge med endog erfaren og oplyst i Finmarkens nærværende Landhusholdning». Til arbeidet foreslår Fieldsted kjøpmannen i Måsøy handel Christian Frost Bredal. ${ }^{47}$

Av det forutgående, særlig bruken av begrepet «Jordinddeling», synliggjøres det at Fieldsted foreslo utskifting av jordsameie. Dette bestyrkes av følgende uttalelse knyttet opp mot antatt tidsforbruk (som optimistisk var beregnet til to somre):

Der som ikke Landinddelingen havde til Øjemerke saa vel at inddeele og udmærke Rydnings

Marken, som at $u d s k i f t t e$ og sætte Grændser for de nu beboede Pladser, saa Kunde vel

Forrettningerne have hastigere Fremgang. ${ }^{48}$

For øvrig er ikke amtmann Fieldsted den første som har tanker om jordskifte i Finnmark. Allerede i 1745, under arbeidet med å fastlegge den norsk-svenske riksgrensen, drøfter major Peter Schnitler å få «Jordens Brug imellem Indbyggerne, til hvers særdeles Nytte og Landets almindelige Forbedring, skifted». Dette var imidlertid «u-forgribelig: Efterdi det for de faa Kongelige Betienter ville blive for langvarigt og vidløftigt». ${ }^{49}$ Når det gjaldt Indre Finnmark foreslo han å vente inntil landegrensen var fastlagt og «man da kan vide, hvad man har at skifte». ${ }^{50}$ [233]

\subsection{Kgl. Resolution ang. Jordbrugets Inddeling til visse Boepladser i Finmarken}

Fieldsteds forslag må ha falt i smak hos Rentekammeret, for allerede 27. mai 1775 la det fram Allerunderdanigst Forestilling $n r .24$ for Kong Christian VII. ${ }^{51}$ Forestilling var datidens proposisjon eller komitéinnstilling, og den inneholdt et utkast til resolusjon, samt en fortale som viser resolusjonens formål. Det var «at bringe Jordbruget i Finmarcken til en ordentlig og bedre Benyttelse end det hidtil har været». Derfor har det:

behaget Ærbød. Maj ${ }^{\text {ts }}$ ved allernaadigst Resolution af 22de indeværende Maaned at udnævne en Landmaaler, som med Hielp af en holdende Assistent, [...] have at besørge Jordbrugets Uddeling efter den ham tillæggende Instruction og videre Anstalter, som derom blev at føie.

Rentekammeret ønsker med dette å forbedre jordbruket og å:

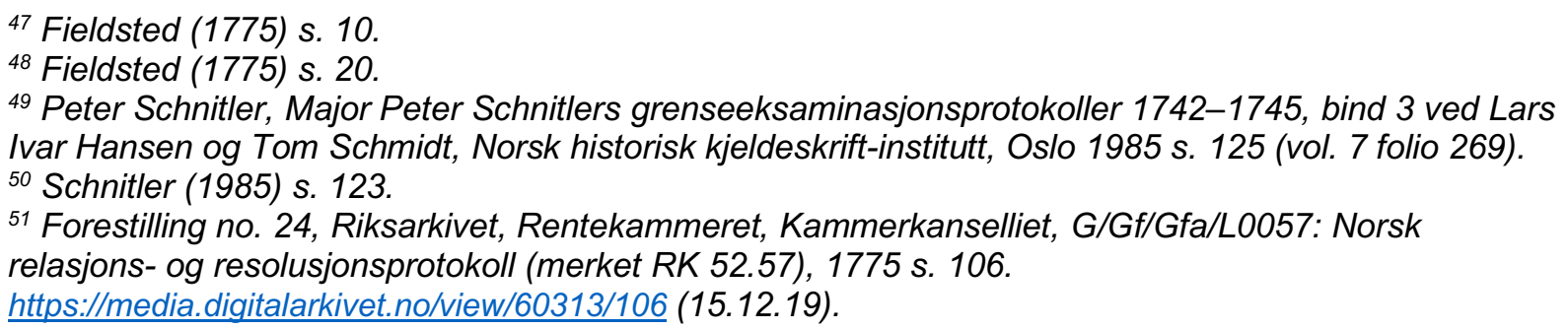


afvænde Indbyggerne fra den hidtil sædvanlige og for Landet skadelige Omflakning, og derimod at tage fast Boepel, der gav dem Leilighed til bedre at anornede Jordbruget, som et Hielpemiddel til deres Underholdning, [...] hvorved og Folkeformerelsen der i Landet var at vente.

Den 8. juni 1775 signerte Kong Christian VII forestillingen, og skriver:

Vi approberer allernaadigst Vaares RenteCammers, angaaende Jordbrugets Inddeling til visse Boepladser i Finmarken, med hvad dertil henhører, forestaaende allerunderdanigste Forestilling i alle Maader, hvorefter, saavel Instructionen for Landmaaleren kand udfærdiges, som de fornødne videre Anstalter herom føies [...]. Fredensborg slot, den 8. Juni 1775. Christian R.

Resolusjonsutkastet inntatt i forestillingen ble altså approbert (vedtatt) av enevoldskongen 8. juni 1775. ${ }^{52}$ Innledningsvis vises det til amtmannens [234] forslag «ang. Jordbrugets Inddeling i Finmarken til visse Bodpladser m. v.», samt egen forestilling. Nevnte tittel må sies å være av interesse med tanke på resolusjonens formål. Likeledes at Rentekammerets formulering «Uddeling» ved approbasjonen er erstattet med «Inddeling».

Deretter vises det til at Kongen har approbert følgende hovedposter til «Efterretning og Iagttagelse» ved denne Forretning. Post 1 i resolusjonen regulerer utleggingen av den enkelte eiers lodd av fellesskapet og lød slik:

1) Til enhver fast Boplads anvises saa megen Grund, som udfordres for en Familie, omtrent til fire Qvægs-Høveders, eller for hvert Høved otte Faars, Græsning og Vinter-Foder, dog at derved iakttages: a) hvor En eller Anden han i Brug visse allerede opryddede Pladser, samme Pladser ham da, saavidt muligt er, tildeles; b) [... (omhandler jord til geistlige og verdslige Betjente)]; og c) hvor Leilighed gives til Rydning, anvises dertil visse Pladser Bostedet til Forbedring.

Post 2 er av ren landmålingsteknisk art. Post 3 til 6 omhandler rettigheter. Her reguleres oppsitternes rett i områdene hvor fellesskapet ikke blir oppløst, herunder i det som er regnet som allmenning. Kongen tar her forbehold om barskogen, og rettigheter han allerede har forpaktet bort på visse øde steder, men gir også regler for tilbakeføring «naar disse Steder erholde faste Beboere, [da] har Amtmanden at gjøre Forslag, hvorledes dermed til Bedste saavel for sammes Beboere som Kongl. interesse videre var at forholde». Ifølge post 6 skal:

\footnotetext{
${ }^{52}$ Resolusjonen er inntatt $i$ sin helhet i Fr. Aug. Wessel-Berg, Kongelige Rescripter, Resolutioner og Collegial-Breve for Norge i Tidsrummet 1660-1813, Andet Bind 1746-1780, Christiania 1842, s. 623 625 under 3. juni 1775 [!] i note bemerket «Anføres sædvanlig under Dato 8 Juni», og i Tønnesen (1972) s. 136-139. Ifølge Simon Trøan, Riksarkivet, brev 5.12.19 (ref. 2019/22285) er 8. juni 1775 (appropriasjonsdatoen), rett dato for resolusjonen (og ikke 27. mai 1775).
} 
De Herligheder, som hidintil have været tilfælles for hele Bygder eller Almuen i Almindelighed, være sig Fiskerie i Havet og de store Elve, samt Landings-Steder og deslige, forblive fremdeles til saadan almindelig Brug. ${ }^{53}$

I post 7 tok kongen ytterligere forbehold, som med dagens øyne kan fremstå som nokså inngripende (men som i enevoldstiden neppe var uvanlig):

De anvisendes Pladser overlades Almuen til Eiendom, med Vilkaar: a) at den i Norge gjeldende Odelsret ei her maa finde Sted; b) de, som antage Pladserne til Eiendom, blive pligtige samme at bebygge; og c) dersom Pladsen [235] forlades øde, og bliver uden Beboere øde henstaaende over tre Aar, er saadan Plads, efter derom erhvervendes lovligt Beviis, Kongen igjen hjemfalden, og bliver til andre at overdrage.

Hvilke begrensninger som her er oppstilt, kommer jeg tilbake til i drøftingene i kapittel 4.

Post 8 påla amtmannen å utferdige skjøter eller eiendomsbrev på plassene, som deretter skulle sendes Rentekammeret for ratifikasjon. Post 9 hadde spesifikke regler for hjemmelsbrev til geistlige, sivile og militære betjenter, mens post 10 hadde regler for årlig avgift (skatt) beregnet ut fra «det Tal Kvæg, som derpaa kan græsses eller fodres Aaret igjennem», hvor det var gjort unntak for de som måtte «holde en Hest eller Oxe til at hjemføre Hø, Vand og Brænde». De som alt bodde på plassene, fikk avgiftsfritak for fem år, mens de som ryddet jord, fikk fritak for 10 år. Post 11 fritok geistlige for avgiftene.

Post 12 innehold en rekke pålegg til amtmannen. Foruten et generelt pålegg i bokstav a om å tilse at «Alting dermed ordentlig tilgaaer», skulle han etter bokstav b avgjøre tvister om «Jordbrugets Uddeling» som måtte forekomme mellom landmåleren og innbyggerne, eller mellom innbyggerne innbyrdes «om Grændsernes Bestemmelse, deres nærværende Brug, formeente Rettigheder m. v.» Videre het det at:

[D]ersom Vedkommende troe sig ved hans [Amtmandens] Decision at være fornærmede, bliver det dem uforment for Rentekammeret at andrage [...] saaledes formene sig være at være fornærmede, at indkomme med deres Paaanke inden sex Maaneder efter at Amtmandens Decision dem er bekjendtgjort.

Her beskrives en måte for å løse tvister på som er naturlig ved utskifting, men neppe om statlig jord skulle utvises. Tvistene kunne ankes til Rentekammeret, omtrent slik de kunne i den danske utskiftningsloven. Post 12 bokstav c til e påla amtmannen å sikre landmålerens arbeid ved å holde bok over han arbeid, kopibok over skjøter og eiendomsbrev, samt årlig å underrette Rentekammeret om

\footnotetext{
${ }^{53}$ Post 6 er ennå i kraft som norsk lov, se henvisning i note 4 ovenfor. 
fremgangen i arbeidet. Etter resolusjonsteksten følger formular for eiendomsbrev og skjøte.

Formularet er inntatt nedenfor.

Forestillingen viser at formålet med resolusjonen om «Jordbrugets Inddeling» er å legge til rette for jordbruket, herunder at allmuen skulle bli [236] bofaste på ett sted. Oppløsning av jordfellesskap med inndeling til eneeie var middelet for å oppnå dette.

\subsection{Resolusjonens skjøteformular og landmålerinstruks}

Sammen med amtmann Fieldsteds promemoria og Rentekammerets forestilling, er landmålerinstruksen og skjøteformularet de viktigste kildene til å belyse hva Rentekammeret og Kongen mente med resolusjonen. Skjøteformularet; «Bemeldte Formular til Eiendoms-Brev eller Skjøde paa en uddeelt Boplads i Finmarken», innledes slik:

Christian den syvende, Konge til Danmark og Norge, ec. Hans Kongl. Majts. allernaadigst beskikket Amtmand over Vardøhuus Amt, N. N., gjør vitterligt: at efter de til mig in indløbne allernaadisgste og høie Ordres, samt efter Landmaaler N. N.'s Beskrivelse og Indberetning om Gaard-Pladsen. . . . . kaldet, anført i Jord-Inddelings-Forretningen for N. N. Sogn Nr., beliggende i N. Fjord Bøygde-Nr. (her beskrives Pladsens Grændser [m.m.]) bliver hermed paa det Kongl. Rentekammers nærmere Ratification, til Opsidderen N. N. afhjemlet til hans rette og lovlige Arvingers fulde Eiendom, saaledes at han samme Jordplads bruger og besidder, som han det kjøbt eller arvet havde, $[\ldots] .{ }^{54}$

I skjøtet finner man intet om overdragelse, men derimot at eiendommen er «afhjemlet til hans [skjøtemottakerens] rette og lovlige Arvingers fulde Eiendom» på sammen måte «som han det kjøbt eller arvet havde».

Deretter følger fire punktvise vilkår, hvor 1) er plikt til å bebygge eiendommen, «samt udreede de Rettigheder, Skatter, Skydsfærd og offentlige Tyngder, som Almuen i Findmarken ere eller vorde paalagte», 2) unntak fra odelen, og 3) hjemfallsretten, jf. resolusjonen post 7 bokstav c og 4) at eiendomsretten ikke måtte gjøre «Hinder i det almindelige Fiskerie». Punkt 5) tillot for øvrig oppsitteren å bosette husmenn og strandsittere.

Landmålerinstruksen regulerte hvordan jorddelingen skulle skje. ${ }^{55}$ Paragraf [237] 6 bokstav a til $\mathrm{f}$ har særlige regler for Alta. Her skal land og engsletter brukt av embetsstanden, prest, lege og handelsfolk utmåles til disse. I de øvrige områdene skal landmåleren, ifølge bokstav g, iaktta samme

\footnotetext{
${ }^{54}$ Wessel-Berg (1842) s. 625-626.

${ }^{55}$ Forslag til landmålerinstruks (som antas å samsvare med den vedtatte) finnes hos Tønnesen (1972) s. 392-397 med referanse kgl. Resolusjoner, $\mathrm{nr}$. 12, 8. juni 1775, Rentekammeret, 1. Nordenfjeldske kontor 1775-77. Indstruction til landmåleren er omtalt av Wessel-Berg (1842) s. 625, hvor det i note står: "Af denne Indstr. Haves ikke Gjenpart; cfr. Instr. 7 Dec. 1785 og Lov ang. Areal-Indholdet af v. F. V. 6 Juni 1816.
} 
orden som i Alta, slik at «Præstegaardernes og dernæst Handelspladsernes Jordbrugs Pladse og Engeslætter først uddeeles fra de øvrige Beboeres Fællesskab, ...». Videre heter det i bokstav h at landmåleren skal ta hensyn til nåværende og senere beboeres behov, og hvor det er mulighet til rydding, skal det anvises plasser til det.

I likhet med amtmann Fieldsteds promemoria, viser $\S 6$ i landmålerinstruksen at resolusjonen siktet mot å oppløse jordfellesskap. Først skulle amtssetet Altagård få utlagt «Det Land og Engesletteer som beviiselig» hadde vært brukt «fra den Tiid Gaarden blev bygget», deretter skulle øvrige embetsmenn og handelsfolk få utlagt sine områder før oppsitterne; allmuen, skulle få utlagt sine engsletter.

Paragraf 8 omhandlet særlige forordninger for «Fæstningsbetienterne paa Wardøen». Den påla landmåleren å kartlegge eksisterende bruk forut for jorddelingen. Paragraf 9 inneholdt regler om beskrivelse og grensemerking. Bokstav $\mathrm{f}$ er her særlig interessant:

Engstykker som ligger i andre Fiorder, eller paa langt bortliggende Stæder fra den Plads, under hvilket de efter forhenværende Brug have henført, skal hand søge at ombytte med andre, som ligger beleilig for hver Opsidder, saaledes, at Pladsernes Jordbrug kand vorde samlet saavidt mueligt er og Landets Beskaffenhed det tillader (min uth.).

At landmåleren pålegges å ombytte engstykker, viser at man har med utskifting, og ikke utvisning, av jord å gjøre: Bestemmelsen sier at landmåleren kunne bytte teiger oppsitterne allerede hadde i sin besittelse for å forbedre jordbruket. En slik regel er unødvendig om hensikten var å overdra jord fra staten til oppsittere.

Også $§ 10$ synliggjør at resolusjonen initierte en utskiftning, både fordi den beskriver ombytte av teiger, og måten tvister skal løses på. I første punktum heter det at:

Dersom ved Uddelingen af de brugbare eller opryddede Engesletter, eller ved den nysnævnte Ombytning, kand opkomme nogen Tvistighed imellem dem som Egnere tildeles, og dem som de efter Omstendighederne fratages, [238] skal Landmaaleren tage 2de uvillige Mænd fra hver Siide, og selv den 5te tilholde dem at siige sin Meening om Sagen og skal hand derpaa siige sin endelige Kiendelse i sin Protokoll.

Saken kunne så bringes inn for amtmannen og endelig for Rentekammeret. Både karakteren av de saker som kunne lede til tvister, og måten tvistene skulle løses på, er betegnende for utskiftningsaker, og gjenfinnes som nevnt på liknende måte i den danske utskiftingsloven fra 1781.

Paragraf 11 omfattet delingen, hvor landmåleren skulle tilse at plassene «bliver lige store». Dog måtte han iaktta:

at den opryddede Engbund, som enten en Plads Opsidder selv, eller og Opsidderens Fader [...] af egen Drift og Vindskibelighed, have ryddet, eller ved Strævsomhed giort brugbar, maae komme den som paa Jordens Forbedring har arbeidet, eller hands Arvinger, til Nytte. 
Paragraf 12 omhandlet matrikulering og skyldsetting, noe som var viktig med hensyn på skattlegging. Paragraf 13-17 har bestemmelser om bruk av øde plasser og skog, mens $§ 18$ hadde en krevende bestemmelse om kartlegging. ${ }^{56}$

\section{Samtidige beskrivelser i litteratur og i innberetning fra amtene}

\subsection{Bings beskrivelse av kongeriket Norge - og jorddelingen i Finmarken}

Samtidig litteratur kan i atskillig grad kaste lys over hva 1775-resolusjonen ledet til. Et viktig slikt bidrag er Beskrivelse over Kongeriget Norge fra 1796 av Lars Hess Bing. I omtalen av Finmarkens Amt skriver Bing at «Allerede ved Amtmand Collers Betænkning, Aar 1757, foresloges om Jorddeling», men den ble ikke til realisert før ved Kgl. befaling av 27 Mai 1775: [239]

Der bleve da 2de Landmaalere ansatte, en i Østfinm., og en i Vestfinm., den siste med en Assistent. I Østfinmarken blev Jorddelingen til visse Boepladse igjen ophævet, formedelst de dermed forbundne Vanskeligheder, som flød af Landets Beskaffenhed, Indbyggernes Tænkemaade og omflakkende Levemaade, den de ikke paa den Tid være at formaae til at omvexle med faste Boepæle, saa at altsaa Jorddelingen vilde være unyttig. ${ }^{57}$

Jorddelingen i Vest-Finnmark, fortsetter Bing, hadde fremgang «og blev fuldført Aar 1789 over alle til den Tid opryddede og indtagne Jorder eller Engesletter, og Eiendoms Skiøder paa de uddeelte Pladse bleve givne». Dette resulterte i matrikulering av jorder til 629 boplasser i tinglagene Hammerfest, Loppen, Hasvig, Maasøe, Alten og Kiælvig [dagens Nordkapp og Porsanger kommune]. ${ }^{58}$

Hva er det så Bing, som både var utdannet topograf og jurist, og således velkvalifisert til å forstå så vel rettslære som landmåling, omtalte? Etter hans formuleringer er det jorddeling som fant sted, altså ikke jordutvisning og statlig tildeling av jord til oppsittere. Videre viser han at man lyktes med jorddelingen i Vest-Finnmark; i Øst-Finnmark sto derimot innbyggernes «Tænkemaade og omflakkende Levemaade» i veien for delingen.

\subsection{Rathkes beretning om Udskiftning og Krafts beretning om Finnmark som sameie}

\footnotetext{
${ }^{56}$ Landmåleren skulle "gjøre sig Fliid og Umage for at afteigne Landets og Fiordernes Strækninger, samt Øernes Situation, saaledes at hand kand [...] bringe et fulstændigt Cart til veie, til Forbedring og Efterretning udi den geographiske Kundskab om denne nordligste Strækning af Kongeriget Norge». ${ }^{57}$ Lars Hess Bing, Beskrivelse over Kongeriget Norge, Øerne Island og Færøerne, samt Grønland, Kiøbenhavn 1796 s. 146.

${ }^{58}$ Bing (1796) s. 147.
} 
Bing er ikke den eneste som gir et slikt samtidsbilde av jorddelingen. Jens Rathke, fra 1813 Norges første professor i zoologi, besøkte Finnmark i 1802. Han skriver at:

Landets Udskiftning til Eiendom fandt som bekiendt til Uheld saa meget Modsigelse i

Østfinmarken, at den ei kunde iværksættes. ${ }^{59}$

Han utdyper dette med å påpeke at landbruket har «mangfoldig naturlig Hindring». En av dem er manglende utskifting: Den fant «i Østfinmarken saa megen Vanskelighed og Modsigelse, at den ei blev foretaget. Græsset [240] kan altsaa ikke fredes til Høeslet uden i afsides Egne». ${ }^{60}$ At folk ikke kunne slå høy til vinterfôr, medførte også at sommeren måtte brukes til å hente «Reenmosse fra fælles Districtet eller Raftesiden til Qvægets Vinter foering».

Rathke bekrefter dermed at det hadde funnet sted jorddeling i Vest-Finnmark, men ikke i ØstFinnmark. I motsetning til Bing, nyttet Rathke begrepet utskifting (i dag jordskifte). Ut fra disse skildringene kan det legges til grunn at det hadde funnet sted utskifting i deler av amtet, men derimot ikke jordutvisning.

Oppfatningen om at jorddeling eller utskifting var gjennomført i Vest-Finnmark, synes for øvrig å ha vært nokså etablert på denne tiden. Både professor i lovkyndighed Johan Frederik Schlegel, amtmann Ole H. Sommerfeldt og jurist og historiker Jens Kraft, skriver i hhv. 1793, 1799 og 1835 at det har funnet sted jorddeling i Vest-Finnmark, men ikke i Øst-Finnmark. ${ }^{61}$

Vel så interessant som Krafts beretning om jorddelingen, er hans utsagn om at «hele Landet [i Finmarken] var et Staten tilhørende Sameie, hvoraf Indbyggerne i Flæng betjente sig». ${ }^{62}$ Landet i Finnmark var altså et sameie. Med «Staten tilhørende» sikter nok Kraft til statens overeiendoms- eller høyhetsrett, ${ }^{63}$ dvs. at landet var en del av staten Norge. Om han mente at landet var statens private eiendom, ville utsagnet om sameie vært selvmotsigende.

Når Kraft samme sted skriver at «Grundeiendom har ikke været indført i Finmarken førend efter 1775», kan det peke på at han nyttet begrepet «eiendom» på jord som er skiftet og delt til eneeie. Kraft nevner for øvrig ikke at det kom bureisere til Finnmark for å rydde jord, slik tilfellet var i «flere af Senjen og Tromsøe Fogderies Dale i senere Aar».

\footnotetext{
59 Jens Rathke, Afhandling om de norske fiskerier og beretninger om reiser i aarene 1795-1802 for at studere fiskeriforhold m.v., Bergen 1907 s. 144.

${ }^{60}$ Rathke (1907) s. 153.

${ }^{61}$ Joh. Fredrik Wilhelm Schlegel, Statistisk Beskrivelse af de fornemste europæiske Stater, Første Deel, Kiøbenhavn 1793 s. 241, Ole H. Sommerfelt, "Kort Beskrivelse over Finmarken», Topografisk Journal for Norge, bind 7, 1799, s. 144 flg., gjengitt etter Sandvik (1993) s. 364 og Jens Kraft, Topografisk-Statistisk Beskrivelse over Kongeriget Norge, sjette deel, Det Nordenfjeldske Norge, Anden Deel, Christiania 1835 s. 611.

${ }^{62}$ Kraft (1835) s. 560.

${ }^{63}$ Se punkt 1.4 ovenfor.
} 


\subsection{Oversikt over jordfellesskap og utskiftinger i Trondhiems stift per 1803}

Som vi har sett i kap. 2.1, hadde det pågått et arbeid med å få i stand en utskiftingslov for Norge tilbake fra 1780-tallet. Det tok tid, og etter flere [241] forsøk sendte Rentekammeret i 1803 ut sitt andre utkast til en utskiftingslov for Norge. ${ }^{64}$ Sammen med høringer til utkastet ble amtmennene bedt om å innhente opplysninger om det hadde forekommet utskifting i amtet. Ut fra svarene laget Rentekammeret en oversikt over jordfellesskap og avholdte utskiftinger i Norge. Oversikten, som er gjengitt av O. Juvkam i Tidsskrift for Det norske Utdskiftningsveesen, 1917, innehar detaljerte opplysninger for de enkelte amter, herunder Finmarkens. ${ }^{65}$

Under Trondhiems stift, som bl.a. omfattet Nordlands og Finmarkens Amt, kan man for Nordland lese at «Paa de allerfleste Gaarde er alt i Fælledskab under Navn av Teigskifte, Aarbytte og Hopmark, det sidste er med Hensyn til Skov». For Finmarkens Amt er det kort anført «Ligeledes». ${ }^{66}$ Med andre ord mente amtmann Martin A. Unmack i Finnmark at det meste av jorda i amtet lå i teigblanding eller jordfellesskap.

På spørsmål «C:/Har Udskiftningen været attraaet forsøgt og fuldført og hvorledes var Fremgangsmaaden», finner man for amtene under Trondhiems stift følgende svar: For Trondhiems Amt er «Betydelig fremgang hermed [...] ej giort». I Romsdahls Amt er «Udskiftningen [...] af mange attraaet men af faa forsøgt og fuldført». For Nordlands Amt heter det at «[d]et Tilfældet at nogen har forlangt Udskiftning, har aldrig forekommet Amtmanden». For Finmarkens Amt, derimot, kan man, nokså uventet, lese: «Udskifting i senere Tiid er meget attraaet og udført ved Sorenskriver og Mænd samt angrændsende Naboers Tilkaldelse». ${ }^{67}$ For Finmarkens Amt ble det videre (under spørsmål D) anført at det er «uden for al Tvivl at Udskiftning forhøier Eiendommens Værd, da først faaer Landmanden Lyst til at forbedre Jord og Mark». ${ }^{68}$

Svarene til Rentekammeret viser at innen Trondhiems stift hadde Finmarkens amt hatt det største omfang av utskiftninger og den beste erfaring med det. Av det må vi kunne anta at det forelå et betydelig jordfellesskap, [242] og trolig teigblanding, i Finnmarksbygdene på 1700-tallet, og at en del av dette, navnlig i Vest-Finnmark, ble utskiftet av landmåler Frost Bredahl i perioden 1776-1789, og antakelig av en sorenskriver «med Mænd» $\mathrm{i}$ årene fram mot 1803.

\footnotetext{
${ }^{64}$ Juvkam (1917) s. 44. Det første utkastet, utsendt i 1786, ikke var fulgt opp i København.

${ }^{65}$ Juvkam (1917) s. 43-56.

${ }^{66}$ Juvkam (1917) s. 48. Ennå i 1859 lå mer enn halvparten av jorda i Nordland $i$ «fellesskap», se Langnes (2019) s. 281.

${ }_{67}$ Juvkam (1917) s. 52 (min uth.). I Juvkam (1948) reflekteres det ikke over disse viktige opplysningene. Selv om Tromsø og Senjen fogderi på dette tidspunkt en del av Finmarkens amt er det lite sannsynlig at det er disse fogderiene amtmannen siktet til, jf. også innberetningen fra Nordlands Amt. ${ }^{68}$ Juvkam (1917) s. 54
} 
Dette viser også at det fantes private eiendommer i Finnmark i 1775, og at resolusjonen ikke åpnet for utvisning av jord fra staten til private. For hadde det vært tilfelle, hadde det naturlig nok ikke vært behov for utskifting; verken av teigblandet jord eller sameie. ${ }^{69}$

\subsection{Hvorfor utskifting i Vest-, men ikke i Øst-Finnmark?}

Som vi har sett, lyktes man med utskiftingen i Vest-Finnmark, men ikke i øst. Det kan spørres om hva som er grunnen til det, noe som kan forklares i flere forhold. For det første ble det satt inn størst ressurser i vest, bl.a. fikk landmåleren her tildelt en assistent og en mer detaljert instruks, samtidig som landmåleren var fra området og må antas å ha kjent stedene og kulturen godt. Dessuten var jordbruket mer etablert i dette området, både som følge av større befolkningstetthet, flere norske og kvenske innflyttere, embetsfolk og ikke minst et bedre klima hvor man i gode somre kunne dyrke frem korn. Det gjorde nok at folk i større grad så fordeler av å få utlagt jord i eneeie. Innflyttingen innebar nok også mindre kulturelle forskjeller mellom embetsfolkene og allmuen.

Videre må det vektlegges at amtmannen hadde sitt sete i Alta i perioden 1738-1814. Dette er viktig; i den grad landmålerne som arbeidet med jorddelingen møtte motstand, var hjelp og støtte kun oppnåelig ved å «tilskrive Amtmanden, som derpaa skal søge at raade Bod, og være Landmaaleren behielpelig [...]», jf. landmålerinstruksen $§ 21$. Slik støtte var neppe særlig effektiv i Øst-Finnmark, $300-400$ veiløse kilometere unna amtssetet. ${ }^{70}$

Ser vi på Øst-Finnmark, kan det også pekes på at det eksisterte et betydelig antall eiendommer i eneeie på 1770- og 80-tallet, noe som fremgår av [243] nedtegninger i kirkebok for Vadsø sogneprestembete. ${ }^{71}$ Det tyder på at det eksisterte lokale sedvaner og oppfatninger om eiendomsrett, noe som kan ha bidratt til å vanskeliggjøre utskiftingen. Det understrekes av Bings anførsel om at befolkningens «Tænkemaade og omflakkende Levemaade» var et hinder for jorddelingen.

At utskifting eller jordskifte ikke sjelden blir møtt med uvilje og motstand hos innstevnede grunneiere, er for øvrig ikke ukjent. Ei heller at utskifting i nyere tid ikke har latt seg gjennomføre i samiske og kvenske bygder som følge av bygdefolks motstand. Et eksempel er Børselv i Porsanger,

\footnotetext{
${ }^{69}$ Norge fikk sin utskiftningslov først etter bruddet med Danmark, jf. lov 17. August 1821 angaaende Jord og Skovs Udskiftning av Fællesskab. Det var imidlertid avholdt enkelte innmarksutskiftninger på 1790-tallet i medhold av NL 3-12-15.

${ }^{70}$ Fieldsted (1775) s. 13 beskriver datidens kommunikasjon slik: «De maae engang for alle erindres om Reiser i Finmarken, at de [...] alle nødvendigste maae skee til Søes og ikkuns faae Stæder dog om Vinteren foretages til Lands».

${ }^{71}$ Ravna (2017) s. 18-26 med henvisning kirkebok for Vadsø sogneprestembete (1764-1821) og Registeringssentralen for historiske data (RHD), vielser i Vadsø prestegjeld fra 1779 til 1790. Registeringen i kirkeboka var et resultat av en handelsforordning 20. aug. 1778 (\$ 41) som krevde dokumentasjon på eiendom før ekteskap kunne inngås. Forordningen er gjengitt hos Jacob Henric Schou, Chronologisk Register over de Kongelige Forordninger og Aabne Breve, som fra Aar 1670 af ere udkomne, VII Deel, fra 1778 til 1780, Kiøbenhavn 1795 s. 97. Resolusjon 29. april 1790 opphevet bestemmelsen.
} 
hvor misfornøyde parter i en utskifting i 1947 truet med å fjerne grensesteiner, og hvor lensmannen måtte tilkalles for å roe gemyttene. ${ }^{72}$

Mer kjent er det samtidige tilfellet fra Manndalen i Kåfjord kommune i Troms, hvor landmåleren aldri kom så langt at han fikk utarbeidet noen skifteplan og foretatt teigutlegging, men derimot ble truet og fysisk hindret av bygdefolk med «stokkar, stein, staurar, sigdar, lange knivar [...] [og] møkkagreip» før han ble satt på lokalbåten med billett til Tromsø. ${ }^{73}$ Landmåleren ble sendt tilbake med politieskorte, uten at han lyktes med å gjennomføre utskiftingen. Senere forklarte han problemene som var oppstått med at «alt låg mange hundre år tilbake der. Tankesett, levemåte o.s.v.». I det rettslige etterspillet som fulgte, ble fire personer dømt i Nord-Troms herredsrett, men frifunnet i Hålogaland lagmannsrett. ${ }^{74}$

At en enslig landmåler, uten assistent, og som ikke kunne forvente særlig hjelp fra amtmannen 300$400 \mathrm{~km}$ unna om problemer oppsto, ikke lyktes med utskifting på 1780-tallet, bør således ikke forundre noen. Særlig ikke når denne landmåleren, danske Ole Nikolaj Giørup, i motsetning til Frost Bredal, kom til en kultur med et annet språk, sedvaner og rettsoppfatninger [244] enn det han kjente fra sitt hjemland. Nettopp annet språk, kultur og samiske sedvaner kan dermed ha skapt problemer for utskiftingen i Øst-Finnmark.

\subsection{Om statens allmenninger i Finmarken, jord uten kgl. skjøte og 1863-loven}

Etter at unionen med Danmark opphørte, ønsket Stortinget å kartlegge statens eiendommer. Etter en noe famlende start krevde Stortinget i 1824 fortgang i arbeidet, hvor det ba om en «[f]uldstændig Fortegnelse over de Staten tilhørende Eiendomme og sammes nutidige Anvendelse, det være sig Jordegods, Skove, Almindinger, Værker, Fabrikindretninger [...]». ${ }^{75}$

Steinar Pedersen har vist hvordan myndigheter på amtsnivå vurderte henvendelsen. For Finnmark påla amtmann Johan C. Krogh, med sete i Tromsø, fogdene å redegjøre for statens allmenninger. Resultatet av undersøkelsen ble at amtmannen i nokså vage formuleringer konkluderte med at det eksisterte «Staten tilhørende Almindinger» i Vest-Finnmark, og at lokalbefolkningen hadde rettigheter til hogst og beite - som i landet for øvrig. Til forskjell fra hans kollega i vest, så fogden i Øst-Finnmark ingen hensikt i å kartlegge om staten eide allmenningsgrunn eller annen eiendom. Ifølge Pedersen kom det av den helt klare oppfatningen fogden selv hadde av eiendomsforholdene. I et kortfattet brev til

\footnotetext{
72 Geir Wulff, «Seljemark Søndre», Ságat, 26.01.1994 s. 9.

${ }^{73}$ Øyvind Ravna (red.), Jordskifterettene i Hålogaland. Historikk, jurisdiksjon og saklig kompetanse, Vadsø 2003 s. 21.

${ }^{74}$ Hålogaland lagmannsrett, dom 28. jan. 1950 (sak 8-11/1950), i Statsarkivet i Tromsø/ SATØ/S0066/F/Fa/Fac/L0068.

${ }^{75}$ Pedersen (2001) s. 300.
} 
amtmannen skriver han at «forsaavidt Øst-Finm. betræffer, skulde jeg herved give mig den Frihed at indberette at saavidt mig bekiendt, existerer ingen Staten tilhørende Almindinger i Øst-Finm». ${ }^{76}$

Opplysningen fra fogden kunne knapt nok ha vært kontroversiell. I motsetning til for VestFinnmark, noterte amtmann Krogh i journalen over innkomne saker kun at fogd Nielsen «melder at i Øst-Finmarken ikke existere nogen Staten tilhørende Almindinger». ${ }^{77}$

At det eksisterte selveide, umatrikulerte eiendommer i Øst-Finnmark, og at det i svært liten grad hadde forekommet jorddeling der ennå i 1826, synliggjøres av protokollen til Finnmarkskommisjonen av $1826 .{ }^{78}$ Kommisjonen holdt møter langs kysten av Finnmark, hvor den mottok [245] redegjørelser fra embetsmenn, handelsfolk og allmuen. På møtene ble spørsmålene organisert etter et fast oppsett hvor punkt 5, «Landbruget angaaende», er det mest interessante i vår sammenheng.

Fra møtene i Vardø og Vadsø hhv. 3. og 7. juli 1826 finnes nokså like opplysninger om at det ikke eksisterte skyldsatt jord i sognet. ${ }^{79}$ Fra møtet på handelsstedet Mortensnes i Nesseby 10. juli 1826 finnes det mer omfattende informasjon om eiendomsforholdene:

Der blev Forklaret, at ingen i dette Sogn har Kongl Skjöde paa sin Jord, derimod have endeel af Beboerne paa den nordre Side af Fjorden faaet deres Jorder opmaalte og skyldsatte. Mange i Sognet bruge forövrigt Jord uden at have Amtsseddel eller Kgl Skjöde paa samme. ${ }^{80}$

En del beboere hadde altså fătt jorda oppmålt og skyldsatt, men ikke matrikulert, noe som peker på landmåler Giørups ufullførte arbeid, og bekrefter dermed det som var nedtegnet i kirkebok fra Vadsø om eiendommer i eneeie på $1770-$ og 80-tallet.

På møtet på handelsstedet Gullholmen i Tanens sogn 13. juli 1826 ble kommisjonen for første gang møtt med beretninger om «[e]iendomsjorder, hvorpaa er udstædt Kgl Skjöder» til sammen 18 i tallet, samtidig som 22 hadde amtssedler. Men også her var «de mange Flere som i Sognet bruge Jord [der] have dertil ingen Adkomst». ${ }^{81}$ Tilsvarende forhold rådet i sognene Lebesby og Kjøllefjord. ${ }^{82}$ Først da kommisjonen kom til Vest-Finnmark, ble det meste av jorden betegnet som «Eiendoms-Jorder» med kgl. Skjøte. Men også her var det «omflyttende Söefinner, der til en Tid bruge egenraadigen tiltaget

\footnotetext{
${ }^{76}$ Pedersen (2001) s. 302.

77 Pedersen (2001) s. 303.

${ }^{78}$ Forhandlings Protocol Commissionen der er nedsatt for at foretage Undersøkelser om Midlerne til Finmarkens Opkomst 1826. http://xml.arkivverket.no/diverse/forhandprotfinnmarkkomm1824-30.pdf (15.12.19).

${ }^{79}$ Forhandlings Protocol (1826) folio $4 a-4 b$ og $7 a$.

80 Forhandlings Protocol (1826) folio $8 b$.

81 Forhandlings Protocol (1826) folio 11a.

${ }^{82}$ Forhandlings Protocol (1826) folio 14b. Dette bekreftes av Kraft (1835) s. 611 som skriver at «I Vest-Finmarken har Jord-Uddelingen gjort gode Fremskridt [...], i Øst-Finmarken [hadde] hvor JordUddelingen endnu i 1828 kun havde fundet Sted i Kjøllefjords og Tana Thinglauge».
} 
Jord og udhugge den derved værende Skov, hvorefter de paa samme Maade fraflytte til et andet Sted». ${ }^{83}$

I motsetning til fogd Nielsen i Øst-Finnmark, mente kommisjonen at all jord som ikke var bortskjøtet, tilhørte staten. Like fullt observerte kommisjonen «et Fælledsskab [...] mellem Staten og Eierne af Engstykkerne». [246]Dette fellesskapet var så omfattende at kommisjonen forslo det utskiftet i medhold av utskiftingsloven av 17. august 1821. Utskiftingen skulle ifølge loven «skee saaledes, at hver Lodseier faar det som tilfalder ham, saavidt mueligt, samlet paa et Sted». ${ }^{84}$ Kommisjonen innså at utskiftingen ville være vanskelig da «Udskiftningen hos Mængden af dem som eie Engstykker, og som ei indsee deres eget Bedste, vil möde stor Uvilje».

Knappe fire tiår senere, 22.juni 1863 ble Lov om Afhcendelse av Statens Jord i Finmarkens Landdistrict vedtatt. Med den blir betegnelsen «statens jord» eller «statens grunn» for første gang nyttet i norsk lov. ${ }^{85}$ Betydningen av loven kommer jeg tilbake til nedenfor.

For øvrig nevnes det at Knut Spilling, som ikke var i tvil om at staten hadde eid «al jord og grund med tilbehør» i Finnmark, ${ }^{86}$ støtte på et jordfellesskap da han arbeidet som jordkommisær i Finnmark om lag 100 år senere (fra 1917 til 1922). Selv om han forklarer dette med uheldig jordutvisning i 1780 og en senere ufullstendig deling, må han ha undret seg over dette idet han fremhevet «at der ved jordutvisningen fra det offentlige ikke istandbringes noget sameie eller nogen teigblanding, $-\mathrm{i}$ det hele tat ikke noget fællesskap $[\ldots] \gg .^{87}$

\section{Drøfting}

\subsection{Vurdering av noen sentrale forsknings- og utredningsarbeider og deres betydning}

\subsubsection{Tønnesen og retten til jorden i Finnmark}

Den første til å bestride læren om statens grunn var som nevnt Sverre Tønnesen. Han kom til at hensikten med 1775-resolusjonen ikke var å sikre statens rettigheter, men å skaffe finnmarkingene et

\footnotetext{
${ }^{83}$ Forhandlings Protocol (1826) folio $16 b$.

${ }^{84}$ Forhandlings Protocol (1826) folio 39b. Kommisjonen fremmet dessuten et utkast til inndelings- og utskiftningslov for Finnmark datert 25.11.1826, se Riksarkivet/EA-4036 Utenriksarkivet, serie HArnold Ræstads samlinger av diplomatisk materiale om grenseforhandlinger, underserie $H b$, eske 18: Kommisjonen til Finmarkens oppkomst. Jf. også Vilhelm Haffner, Innstillinger og betenkninger fra kongelige og parlamentariske kommisjoner, departementale komiteer m.m. 1814-1924, Oslo 1925 s. 53.

${ }^{85}$ Sandvik (1993) s. 337 som også viser til at begrepet «Staten tilhørende Strækninger» er brukt i lov 7. september 1854 om fredning av reinbeiter $i$ Øst-Finnmark.

${ }^{86}$ Spilling (1920b) s. 1

${ }^{87}$ Spilling (1920a) hhv. s. 74 og 71.
} 
mest mulig sikkert [247] grunnlag for å kunne livberge seg av det jorda ga ${ }^{88}$ Tønnesen kom også til at hensikten med resolusjonen «var å tillegge finnmarkingene flere rettigheter. Den enkelte skulle gis beskyttelse for sitt personlige bruk [...] ved at eiendomsretten ble fullstendig, slik at rettigheten ble omsettelig». ${ }^{89}$

At 1775-resolusjonen medførte bedre rettsbeskyttelse og omsettelighet, er neppe tvilsomt. Tønnesen anførte også at resolusjonen var en akt med lovs kraft som fastla rettighetene mellom de impliserte partene staten, jordeierne, bygdelaget og allmenheten. ${ }^{90}$ Dette er en riktig beskrivelse som vel også peker på at Tønnesen med jordeiere sikter til oppsitterne. Likeledes er det riktig at resolusjonen respekterte sedvaner og gammel bruk.

Tønnesens avhandling er et betydelig bidrag i avklaringen av retten til jorda i Finnmark. Samtidig synes han ikke å makte å frigjøre seg fra den rådende oppfatning om at 1775-resolusjonen initierte salg eller overdragelse fra staten, idet han skriver at «ved skjøtene overdrar staten den rett den selv har som grunneier». ${ }^{91}$ Han nytter videre betegnelsen «jordutvisningsresolusjon» og begrep som «det samiske aspekter ved jordsalget». ${ }^{92}$ Salgsforutsetningen er dermed lite problematisert, samtidig som Tønnesen i liten grad skiller mellom retten til bygdejorda og allmenningen. Ved å legge overdragelsesaspektet til grunn, kan Tønnesen, trolig uten hensikt, ha bidratt til å styrke oppfatningen om at 1775-resolusjonen, på samme måte som 1863-loven, var en forordning som siktet mot at jorda i Finnmark skulle overdras fra staten til oppsittere og rydningsmenn, framfor at den skulle utlegges til eneeie ved utskiftning.

Samtidig er Tønnesen åpenbart inne på at resolusjonen kan ha initiert utskifting, i det han under overskriften «1775-resolusjonen som en 'utskiftning'» drøfter dette og uttaler:

Det man således har for seg, er intet mindre enn en gigantisk utskiftning mellom Kongen, den enkelte bygdemann og bygdelagene. ${ }^{93}$

[248] I hvilken grad det er treffende å sette partene i tre grupper, kan nok diskuteres. Etter mitt skjønn er det primært tale om å skifte ut jordfellesskapet, eller om en vil, siidajorda i bygdene. Dermed er det bygdefolket som er parter og bygdejorda som er utskiftingsobjekt. Tønnesen ser imidlertid for seg utskifting etter «de gamle velkjente funksjonelle eiendomsrettsbegrepene» (hvor en kunne eie skogen, en annen beitet og en tredje grunnen), noe som tilsa at Kongen (som mulig grunneier) kunne ha vært part i utskiftinga. Det kunne han nok gjøre i den grad allmenningsjord (til rydningsformål) blir tatt

${ }^{88}$ Tønnesen (1972) s. 134.

${ }^{89}$ Tønnesen (1972) s. 134 (uthevet av Tønnesen).

90 Tønnesen (1972) s. 139.

${ }^{91}$ Tønnesen (1972) s. 167.

92 Tønnesen (1972) hhv. s. 133 og 150. Eksempelvis nytter Gudmund Sandvik, «Ei forelda lære: 'Statens umatrikulerte grunn i Finnmark'», Lov og Rett 1980 s. 112-125 (s. 113) betegnelsen til Wessel-Berg (1842) "Kgl. Res. 27.5.1775 angaanede Bopladsers Udviisning m. v. i Finmarken.» ${ }^{93}$ Tønnesen (1972) s. 146. 
med i skiftet, men det er mer naturlig tale om to forskjellige forretninger; utskifting av jordsameie og utmål av rydningsjord, hjemlet i hhv. 1775-resolusjonen post 1 bokstav a og bokstav c.

Til tross for at Tønnesen studerte landmålerinstruksen og Fieldsteds promemoria inngående, har han ikke konkretisert utskiftingsprinsippene i disse dokumentene slik at drøftingene hans kunne forankres i datidens mål om å oppløse jordfellesskap. Han har således ikke vektlagt Fieldsteds anførsel om at jorddelingen hadde som mål «[...] at udskiftte og sætte Grændser for de nu beboede Pladser» (min utheving). Med dette mister han en tråd som kunne ledet til en tydeligere konklusjon i hans avhandlingsarbeid.

\subsubsection{Samerettsutvalgets rettsgruppes utredning av retten til land og vann i Finnmark}

Samerettsutvalgets rettsgruppe, sammensatt med datidens fremste tingsrettsjurister, hadde i mandat å «utrede og ta stilling til hva som i dag må anses for å være gjeldende rett med hensyn til eiendomsrett og bruksrett til land og vann i Finnmark fylke». ${ }^{94}$ Den besvarte mandatet med å konkludere «at staten må anses som eier av de tidligere umatrikulerte arealene i Finnmark». ${ }^{95}$ Dette gjaldt ikke bare den ytre delen, men også den indre. Grunnen til statens rettserverv var «festnede forhold» og passivitet fra lokalbefolkningen. ${ }^{96}$ Rettsgruppa var heller ikke særlig imøtekommende overfor eksistensen av bygdefolks bruksrettigheter - selv om den ikke avviste slike rettigheters eksistens fullstendig. ${ }^{97}$ [249]

Som påpekt ovenfor, ble det ikke utvist jord for salg eller bortfeste fra staten før 1863-loven trådte i kraft. Det blir derfor positivt feil når Rettsgruppa, med generell henvisning til Spilling og Tønnesen, anfører at «[s]taten har siden 1775 ved salg og bortfeste overdratt arealer i Finnmark til private». ${ }^{98}$ Det er også positivt feil når Rettsgruppa (samme sted), uten spesifikt å gå inn på resolusjonens formål, innhold eller instruks, konkluderte med at «[d]e første grunnavståelser fra staten til private skjedde i henhold til kongelig resolusjon 27. mai 1775 om jordutvisning i Finnmark».

Noe uventet, sett ut fra konklusjonen Rettsgruppa senere kom til om eiendomsrett (nevnt ovenfor), drøfter den ikke eiendomsretten til grunnen spesifikt, men går i stedet på de funksjonelle delene av eiendomsretten slik som rett til trevirke, utmarksbeite for bufe, saltvannsfiske osv. Først under konklusjonen, som i stor grad omhandler analogier til våre naboland Sverige og Finland (men ikke Danmark), vies eiendomsretten oppmerksomhet.

\footnotetext{
${ }^{94}$ NOU 1993: 34 s. 16. Mandatet var en del av grunnlagsarbeidet for det som ledet til fram til Finnmarksloven.

${ }^{95}$ NOU 1993: 34 s. 266. Et av medlemmene, Otto Jebens, dissenterte når det gjaldt Indre Finnmark (s. 295 og 297). Jebens forsvarte senere dissensen $i$ avhandlingen Om eiendomsretten til grunnen $i$ Indre Finnmark, Oslo 1999.

${ }^{96}$ NOU 1993: 34 s. 259-266.

${ }^{97}$ NOU 1993: 35 s. 252.

${ }^{98}$ NOU 1993: 34 s. 88 med henvisning til Spilling (1920b) og Tønnesen (1972), begge uten sidetallsreferanse.
} 
Eiendomsrett til land og vann i Finnmark har i prinsipiell form aldri vært forelagt Høyesterett. ${ }^{99}$ Det gjør at Rettsgruppas utredning fortsatt er en tung rettskilde for dette spørsmål. Det er tilfellet selv om lovgiver, med henvisning til ILO-konvensjon nr. 169 art. 14, la til grunn at det finnes områder i Finnmark «der det samiske folk har krav på eiendoms- og besittelsesrett», og samtidig foreslo opprettet et grunneierorgan hvor «Sametinget må ha reell og praktisk innflytelse». ${ }^{100}$ Forutsatt 1775 resolusjonens formål og utkomme, er det gode grunner til å reise spørsmål ved Rettsgruppas konklusjoner.

\subsubsection{Niemis utredning om lokalbefolkningen og staten, og Høyesteretts dom i Nesseby-}

\section{saken}

Etter Samerettsutvalget har flere forskere, slik som Steinar Pedersen, Kirsti Strøm Bull og Jon Gauslaa studert 1775-resolusjonen og rettsutviklingen [250] etter denne. ${ }^{101}$ Disse har imidlertid ikke gått inn på utskiftingstematikken som ligger forankret i resolusjonen. Også i mine tidligere arbeider har jeg ikke klart å se hva som nokså utildekket har ligget i resolusjonen og dens forarbeider på dette området. ${ }^{102}$ Heller ikke Einar Niemi drøfter utskiftingstematikken i en studie fra 2017 skrevet for Finnmarkseiendommen og framlagt for Høyesterett i HR-2018-456-P (Nesseby). ${ }^{103}$ Niemi er imidlertid den som i størst grad holder fast ved at resolusjonen initierer statlig jordutvisning, noe som gjør det naturlig å vie hans studie oppmerksomhet her. Det understrekes av at den har fått vesentlig betydning for Høyesteretts vurdering av statens posisjon og disposisjoner i årene etter 1775 i nevnte plenumsdom.

Niemi problematiserer i liten grad resolusjonens formål. Et av hans hovedpoenger er videre at eiendommene beskrevet i kirkebok for Vadsø sogneprestembete i forbindelse med inngåelse av ekteskap (se punkt 3.4), tross ordlyden, var utvisninger i medhold av 1775-resolusjonen. Samlet dreier det seg ifølge Niemi om 72 jordstykker i Vadsø prestegjeld i perioden 1779 til 1789, «alle med henvisninger til giftermål som forutsetning for jordtilegnelse». ${ }^{104}$ Han hevder dermed at resolusjonen, $\mathrm{i}$ motsetning til det som framkommer i litteratur vist til ovenfor, ble aktivt nyttet i Øst-Finnmark; ikke til jorddeling, men til statlig jordutvisning. Dermed avviser han også at de omtale eiendommene kan

\footnotetext{
99 Ot.prp. nr. 53 (2002-2003) Om lov om rettsforhold og forvaltning av grunn og naturressurser $i$ Finnmark fylke (Finnmarksloven) s. 36. Det er gjelder også etter HR-2016-2030 (Stjernøya) og HR2018-456-P (Nesseby).

100 Ot.prp. nr. 53 (2002-2003) s. 90-91. Rettsgruppa er kritisert for ikke å legge vekt på folkeretten og i større grad ta inn over seg «dagens politiske og sosiale realiteter», se Gunnar Eriksen, «Norsk tingsrett i Sapmi - en uting», Retfærd 1995 s. 66-86. For en rettshistorisk studie har denne, og lovgivers anførsler, mindre relevans.

101 Pedersen (2001) s. 291-324 og 311-320, Bull (2014) s. 5-26 og Gauslaa (2017) s. 302-315.

102 Ravna (1999) og (2017).

${ }^{103} \mathrm{Niemi}$ (2017).

${ }^{104}$ Niemi (2017) s. 25. Det er forøvrig uriktig at giftemål var forutsetning for jordtilegnelse; det var det motsatte, at jordeiendom var en forutsetning for giftemål, som var tilfelle, se punkt 3.4 ovenfor.
} 
ha vært etablert uavhengig av resolusjonen. ${ }^{105}$ At 1826-kommisjonen ikke fikk seg forelagt skjøtene for disse antatt utviste og påtenkt matrikulerte eiendommene, forklarer Niemi med at landmålerprotokollen kom bort nokså tidlig.

Niemis argumentasjon om jordutvisning og bortkommen protokoll virker lite overbevisende. Noe av det viktigste landmåleren gjorde, foruten selve oppmålingen, var å utstede dokumenter som ga grunnlag for registrering i datidens grunnbok; panteboka. Det ledet igjen til utstedelse av konge- eller amtsskjøter, noe som er godt dokumentert for Vest-Finnmark [251] i pantebok nr. 1 (1776-1794). ${ }^{106}$ Post 12 i resolusjonen påla dessuten amtmannen nøye å sikre landmålerens arbeid ved å «holde Bog» over hans arbeid. Det blir dermed nokså spesielt å hevde at landmåleren, som ikke sendte inn dokumenter for pantebokregistering, i stedet skulle påse, parallelt med at en potensiell eier skulle gifte seg, at utviste eiendommen ble registret i kirkeboka.

I HR-2018-456-P (Nesseby) viser Høyesterett, med bakgrunn i Niemis utredning, til at det «på grunnlag av en gjennomgang av kirkebøkene, [er] påvist at det skjedde 72 utvisninger av eiendom i Vadsø prestegjeld fra 1779 til 1789» (avsnitt 136). Førstvoterende uttaler deretter at registreringene i kirkebøkene viser at jordutvisningsresolusjonen fikk betydning også i Nesseby, hvor etter det konkluderes med at det materialet som er fremlagt for Høyesterett, «gir klare holdepunkter for at det som ble registrert i kirkebøkene, var utvisninger som hadde skjedd etter bestemmelsene i jordutvisningsresolusjonen» (avsnitt 138).

Det kan ikke utelukkes at standpunktet bidro til at Høyesterett kom til annet resultat enn utmarksdomstolen og frifant Finnmarkseiendommen for krav fra Nesseby bygdelag om rett til å forvalte bruksrettigheter anerkjent av Finnmarkskommisjonen. Selv om det ikke var prosedert på eiendomsrett, viste førstvoterende til at det ikke ville vært grunnlag for slikt krav, bl.a. som følge av statens privatrettslige disposisjoner i området (avsnitt 172).

Finnmarkskommisjonen, som også viser til de 72 eiendommene i Vadsø prestegjeld, ${ }^{107}$ stiller seg kritisk til Høyesteretts standpunkt vedrørende jordutvisning. Det skjer ved at den, med referanse til dommens avsnitt 138, skriver at det som er registrert i kirkebøkene er umatrikulerte eiendommer, og at det av andre er anført at de var etablert uavhengig av resolusjonen. ${ }^{108}$ Etter mitt skjønn er det grunnlag for kommisjonens noe kritiske betraktninger omkring Høyesteretts historieforståelse her. [252]

\subsection{Jordfellesskap og utskifting framfor statens grunn og jordutvisning}

\subsubsection{Betydningen av «læren om statens grunn»}

\footnotetext{
105 Niemi (2017) s. 28.

${ }^{106}$ Pantebok nr. 1 (1776-1794), i Statsarkivet i Tromsø/SATØ, Sorenskriveren i Finnmark, G/Gb/L0001pb: https://media. digitalarkivet.no/view/17338 (24.02.2020).

107 Finnmarkskommisjonen (2019) s. 37.

${ }^{108}$ Finnmarkskommisjonen (2019) s. 37, bl.a. med henvisning til Ravna (2017) særlig s. 18-25.
} 
Det må legges til grunn, slik Tønnesen har gjort, at befolkningen i fjordstrøkene i Finnmark på 1700tallet var berettiget til de områder de hadde brukt i alders tid med en oppfatning som etter «nåtidens mål» ville ha vært eiendomsrett. ${ }^{109}$ Videre har vi sett at 1775 -resolusjonen hadde to hovedmål. Det var 1) å oppløse jordfellesskap til eneeie og 2) legge til rette for rydding av uopptatt jord. Videre kunne teigbytte være aktuelt for jord som alt lå i eneeie.

Det må også kunne legges til grunn at eiendomsforholdene langs Finnmarksfjordene besto av jordfellesskap mellom bygdefolk, mens utmarka lenger unna trolig ble sett på som allmenning. I VestFinnmark ble et betydelig fellesskap delt og skiftet til eneeie fram til 1789. Dette lyktes man ikke med i ØstFinnmark. Det skulle gå om lag 50 år før det ble gjort nye forsøk på å ordne jordforholdene der gjennom matrikulering av eksisterende eiendommer.

Den 22. juni 1863 ble lov om Afhcendelse av Statens Jord i Finmarkens Landdistrict vedtatt. Det er som nevnt første gang betegnelsen «statens jord» eller «statens grunn» nyttes i norsk lov. Med denne loven fikk «læren om statens grunn» sitt rettslige grunnlag. Det fikk raskt feste hos statsforvaltningen og på Det juridiske fakultet i Christiania, hvor Fredrik Brandt i 1867 skrev sin tingsrettsmonografi. Som vist het det $\mathrm{i}$ den at Finnmark «lige fra den ældste Tid [har] været betragtet som den norske Stats Ejendom». ${ }^{110}$

Det er ikke rom her for å gå inn på hva som lå til grunn for denne raske endringen, som nærmest var et Creatio ex nihilo - en skapelse av intet. Det er antatt at den dels var forankret i kulturhierarkiske ideer om at nomadefolk ikke kunne eie jord, dels i en gryende fornorskingspolitikk og dels i sikkerhetspolitiske betraktninger relatert til Russland. ${ }^{111}$

Med 1863-loven ble statens uavkortede eiendomsrett en rettslig kjensgjerning for all usolgt jord i Finnmark; bygdejord som mer fjerntliggende utmark, hvor også allmenningsrett til beite og hogst forsvant og ble erstattet av en påtegning i skjøtet til avhendede eiendommer om havnegang [253] (beite) for et gitt antall dyr på statens tilstøtende eiendom. ${ }^{112}$ Likeledes ble utskifting til utvisning og salg av statens jord. At oppfatninger om jordfellesskap og behov for utskifting også forvant inn i en tåkelagt fortid, ${ }^{113}$ var ikke mer enn naturlig.

\footnotetext{
109 Se kapittel 1.3 ovenfor. Se også Finnmarkskommisjonen (2019) s. 29- 30.

110 Se note 13 ovenfor. Sml. Oth. Prp. No. 21 (1848) om Udfærdigelse af en Lov om Ophævelse af $\S 38$ i Lov af 20de August 1821 om det beneficerede og Statens Gods s. 23.

${ }_{111}$ Nils Oskal, "Det moralske grunnlaget for diskvalifiseringen av urfolks eiendomsrett [...]», NOU 2001: 34 s. 256-265 (s. 259-260), Geir Grenersen, «Finnefondet: et fornorskningsinstrument eller et ekstra lønnstillegg? En gjennomgang av fondets midler til lærerne 1901-1902», Historisk Tidsskrift 2015 s. 609-633 (s. 611-612) og Wenche Brenna, "Samene i Norge: fornorskning og identitetsbygging», NOU 2016: 18 Hjertespråket s. 50-69 (s. 53), A. Geffroy, Sverig og Rusland i det 19. Aarhundre, Kjøbenhavn 1865 s. 209 (om Novembertraktaten av 21. nov. 1855) og Knut Einar Eriksen og Einar Niemi, Den finske fare: sikkerhetsproblemer og minoritetspolitikk i nord 1860-1940, Oslo 1981.

112 NOU 1993: 34 s. 110.

${ }^{113}$ Da Norge fikk sitt utskiftningsvæsen i 1857 ble Finnmark ((utenom Senjen og Tromsø fogdreri) utelatt, se Ravna (1999) s. 132-145.
} 


\subsubsection{5-Resolusjonen som en utskiftningslov}

I motsetning til i 1863, var det på 1770-tallet søkelys på jorddeling og utskifting også i Finnmark. Promemoriaet til amtmann Fieldsted viser at hans forslag kan betegnes som et utkast til utskiftningslov, inspirert av datidens jordbrukspolitikk i København. ${ }^{114}$ Han ønsket i den anledning ikke en jordinndeling basert på fortsatt jordfellesskap, slik foreslått av Paus, men argumenterte for en planmessig utlegging av jord til eneeie. Videre brukte han begrepene jordinndeling og utskiftning.

Det kan dog argumenteres med at det ikke med tilstrekkelig tydelighet framgår at resolusjonen eller landmålerinstruksen sikter mot utskifting, og ikke kostnadsfri utmåling av jord fra staten. Det må imidlertid vektlegges at begrepet «Fællesskab», som er en del av tittelen på den samtidige danske utskiftningsloven, gjenfinnes i landmålerinstruksen. Og videre at den som ryddet «Engbunden» hadde rett på å få nytte den etter jorddelingen. Dessuten er «udskiftte» nyttet i forarbeidene, nærmere bestemt i Fieldsteds promemoria.

Resolusjonens tittel må også vektlegges. Enten man velger tittelen brukt ved Kongens appropriasjon: «Resolution angaaende Jordbrugets Inddeling til visse Boepladser i Finmarken» eller den senere brukte tittelen «Resolution angaaende Jorddelingen i Finmarken samt Bopladses Udvisning [254] og Skyldlægning sammesteds», så signaliser det ikke tildeling av jord fra staten. Måten begrepet «Jordbruget» er nyttet på, tyder på at man i 1775 siktet til gårdsbruket framfor næringen.

I den danske utskiftingsloven nyttes begrepene som «tildelt[e] Jord» og «Inddelingen» i $\S §$ og 7 og «Uddeling til Fællesskabets Ophævelse» i § 27. Tildeling og utdeling utgjør her det man i senere utskiftingslover kalte lodding, ${ }^{115}$ altså utleggingen av teiger etter oppløsning av jordsameie eller ombytte av grunn. Når tilsvarende begreper nyttes i landmålerinstruksen, f.eks. $\S \S 2$ og 6 , må de antas å ha samme mening.

Det må også ses hen til resolusjonens formål, holdt opp mot datidens husdyrhold i Finnmark, som var basert på flyttinger mellom sommer-og vinterbosteder med vedvarende problemer med å skaffe vinterfôr til buskapen. I sitt promemoria påpekte Fieldsted behovet for jordinndeling slik at oppsitterne kunne vite «sine Jordbrugs Grændser og være vis paa til Ejendom for sig og sine at beholde den Plads Han dyrker, optager og forbedrer». Formålet, slik det framgår av Rentekammerets forestilling, gjenspeiler dette. Det var «at bringe Jordbruget i Finmarcken til en ordentlig og bedre Benyttelse» ved «at afvænde Indbyggerne fra den hidtil sædvanlige og for Landet skadelige Omflakning, og derimod at tage fast Boepel». Det ga dem mulighet til «bedre at anordnede Jordbruget, som et Hielpemiddel til deres Underholdning» og «Folkeformerelsen der i Landet». Til å nå dette mål var utskifting datidens

\footnotetext{
114 Fieldsted oppholdt seg i København vinteren og våren 1775, altså da han forfattet sitt promemoria, se Sandvik (1993) s. 363 og (1997) s. 586.

115 Se lov 12. oktober 1857 om Jords og Skovs Udskiftning § 13 og lov 13. mars 1882 om utskiftning $\S \S 36-38$.
} 
virkemiddel. Med jord i eneeie kunne eierne gjerde inn enga og frede den for husdyr. Dermed var det mulig å høste vinterfôr rundt boplassen slik at man ikke trengte å flytte mellom sommer- og vinterbosteder for å sikre buskapen fôr. Med jorda i eneeie kunne oppsitterne også forbedre jorda og unngå årkast og kompliserte fellesoperasjoner.

Et argument mot at 1775-resolusjonen initierte oppløsning av jordsameie, framfor statlig utvisning, kan være at størrelsen på de utlagte eiendommene skulle være like. Her må det imidlertid tas $\mathrm{i}$ betraktning at det ikke eksisterte landskyld i Finnmark, som i alminnelighet ble nyttet som delingsnøkkel ved oppløsning av jordsameie. At hver loddeier fikk tilnærmet like lodd var dermed naturlig. Samtidig må det tas med at oppsitterne skulle få tillagt sine «allerede opryddede Pladser», jf. resolusjonens post 1. [255]

Når det i post 7 heter at «De anviste Pladser overlades Almuen til Eiendom» er det videre, med dagens begreper, lett å se for seg jord som utmåles fra statens grunn til familier eller enkeltpersoner. Men etter datidens begreper var motstykket til «eiendom» ikke statens grunn, men jordfellesskap. Det må man også være klar over når man vurderer betydningen av «de herligheter» som ikke skulle følge eiendommene. ${ }^{116}$ For utover barskogen, er det intet som peker på at disse godene skulle ligge til kongen. Og at det tas forbehold om barskogen, kan like gjerne ha vært av ressursforvaltningshensyn.

En annen bestemmelse som kan tale mot at 1775-resolusjonen initierer jordeling eller oppløsning av sameie, er post 7 bokstav c, som forankrer en hjemfallsrett og sier at «dersom Pladsen forlades øde, og bliver uden Beboere øde henstaaende over tre Aar, er saadan Plads, efter derom erhvervendes lovligt Beviis, Kongen igjen hjemfalden, og bliver til andre at overdrage» (min uth.). Bestemmelsen kan forstås som uttrykk for en kongelig eieroppfatning, jf. det uthevede. Skjøteformularet, som fulgte resolusjonen, og som landmåleren ble pålagt å bruke, hadde imidlertid en noe annen formulering, hvor det het «[...] henfalder den igjen til Hs Maj. Kongen, ligesom den aldrig havde varet $i$ nogens Varge eller Eje» (min uth.). Forskjellene mellom resolusjonsteksten og skjøteformularet kan virke små og tilfeldige. Med formuleringene har en meningsforskjell idet den første peker på kongen som eier, jf. passusen «igjen hjemfalden», mens det siste peker på at udelt grunn ikke har tilhørt noen, jf. passusen «aldrig havde været i nogens Værge eller Eje». ${ }^{117}$

For øvrig må det nevnes at en liknende hjemfallsrett også eksisterte i svensk rett fram til 1789: Tre år med ubetalte skatter gjorde at eiendommene til selveiende skattebønder tilfalt Kongen uten erstatning. Kongen kunne da ta opp en ny bruker, som imidlertid bare ble kronobonde, dvs. leilending. ${ }^{118}$

116 Tønnesen (1972) s. 142-143.

117 Finnmarkskommisjonen (2019) s. 189 mener at hensikten med klausulen «nødvendigvis [ikke var] å markere at staten var eier», men å oppfordre de som hadde fått utmålt eiendommer om å fortsette bruken, eller for det tilfellet det dreide seg om «nye» eiendommer, ta disse i bruk.

${ }^{118}$ Nytt juridisk arkiv avd. 1 (NJA) 1981 s. 1-253 (s. 184). 
Det må videre tas med at kongemakten nokså fritt kunne gripe inn i privat eiendom og andre rettigheter da vern av eiendom som nevnt i liten grad eksisterte i enevoldstiden. [256]

Post 12 bokstav b, som omhandler behandling av «Tvistigheder ved Jordbrugets Uddeling [...] imellem Landmaaleren og Indbyggerne, eller mellem Indbyggerne indbyrdes, om Grændsernes Bestemmelse, deres nærværende Brug, formente Rettigheder m.v.» peker også på at 1775resolusjonen ikke tok sikte på å utvise jord fra staten, men på en mer rettsbetont prosess. Vel kunne det også ved utdeling av statlig jord være behov for ordning for tvisteløsning, men neppe en med ankeadgang til Rentekammeret i København lik den rettsmiddelordning som finnes i den danske utskiftingsloven av 1781 .

Til slutt nevnes at et av de sterkeste argumentene for at det verken er salg eller statlig utdeling som ble initiert gjennom resolusjonen, utover det helhetlige bildet av jordeling som gis, er at delingen var kostnadsfri. Staten drev heller ikke den gang med veldedighet, og hvis vi ser til Tromsø og Senjens fogderi, solgte kongen omtrent samtidig allmenningen til godseier Johan Hvid for et betydelig beløp. ${ }^{119}$

\subsubsection{Dispositive utsagn}

Før vi eventuelt kan konkludere med at bygdejorda lå i sameie, må vi forholde oss til noen dispositive utsagn som kan peke i motsatt retning. Vi kan da begynne med amtmann Fieldsted, som i promemoria av 31. mars 1775 uttaler at «al Landgrunden i Finmarken ansees som Uafdeelt Alminding Hans Majestet alleene tilhørende». Dette kan peke på at alt land i Finnmark ble betraktet som Kongens allmenning. Dette står imidlertid i motsetning til amtmannens ønske om deling av jordfellesskapet. Hadde all jord vært allmenning, kunne boplassene og rydningsjorda vært ordnet og utdelt etter reglene i NL 3-12-7 og 3-12-8. For øvrig må begrepet «Uafdeelt» vektlegges da det peker på foreliggende jordfellesskap. Det er videre tenkelig at Fieldsted med «Alminding Hans Majestet alleene tilhørende» siktet til Kongens overeiendomsrett.

Også amtmann Sommerfeldt uttalte (i 1799) at «Landet har hørt Kongen til og tilhører ham endu, forsaavidt ej er skyldsat og solgt». Men det kan [257] ikke utelukkes at han siktet til den jord som var omtalt i setningen foran, altså «den der uryddede og udyrkede Jordsmon». ${ }^{120}$

Det er imidlertid et faktum at embetsmenn utover 1800-tallet fikk klare oppfatninger om statens eiendomsrett. Ser vi på Finnmarkskommisjonen av 1826, gir den uttrykk for at «al den Jord i Finmarken som ikke er blevet bortskjötet» tilhører staten. Mot disse utsagnene, som alle ble gitt av

\footnotetext{
119 Bjørn Bjerkli, «Samisk befolkning, bruk av naturen og rettighetsforhold i Nord-Troms», NOU 2007: 14 Samisk naturbruk og rettssituasjon fra Hedmark til Troms s. 371-410 (s. 396). Jf. Finnmarkskommisjonen (2019) s. 189 (for salg av sør-norske allmenninger) med henvisning til Otto Jebens, Om eiendomsretten til grunnen i Indre Finnmark, Oslo 1999 s. 454.

120 Sommerfelt (1799) s. $144 \mathrm{flg}$.
} 
sittende eller tidligere amtmenn; ${ }^{121}$ statens øverste representant $i$ amtet, står fogd Nielsens utsagn om at han ikke kjente til noen allmenning i Øst-Finnmark tilhørende staten. Videre må det påpekes at Schlegel, Bing og Rathke, som ikke var bundet til staten, ikke nevnte noe om at jorda i Finnmark tilhørte staten eller Kongen, men derimot at det hadde foregått en jorddeling eller utskifting, noe som ikke er forenlig med statlig eierskap. Også amtmannen i Finnmark, Martin A. Unmack, rapporterte i 1803 om at det hadde funnet sted utskifting «i senere Tiid» i Finnmark.

Og kanskje viktigst, uttalelsene til de nevnte embetsmenn er ikke, i motsetning til eksempelvis en kongelig appropriasjon, dispositive eller autoritative i rettslig forstand. Embetsmennene har ganske sikkert gitt uttrykk for sin oppfatning, uten at det i seg selv forplikter. Videre kan de like gjerne ha siktet til Kongens overeiendoms- eller høyhetsrett, som var en del av enevoldstidens rettslære. For det er ingen autoritative statlige akter som slår fast at jorda i bygdene i Finnmark tilhører staten før nevnte lov fra 1863. At det forelå en oppfatning om at allmenningen tilhørte kongen, som en del av hans høyhetsrett, og at det kan ha ført til forvekslinger, endrer ikke dette faktum.

Det må dessuten nevnes at ingen, verken embetsmenn eller akademikere, omtaler det som kom ut av 1775-resolusjonen som «jordutvisning», men derimot som jorddeling eller utskiftning.

\section{Avslutning}

Det har vært en overraskende akademisk reise å oppdage at det er så vidt mange indisier i forarbeidene til 1775-resolusjonen og i dens landmålerinstruks som peker på at resolusjonen initierte utskifting, og ikke utvisning [258] av jord fra staten. Holdt opp mot samtidig dansk lovgivning, jordbrukspolitikk, juridisk begrepsbruk og akademisk litteratur, kan det med stor sannsynlighet sies at resolusjonen la til rette for utskifting av jordfellesskap. Vi har også sett at Sverre Tønnesen var av samme oppfatning, selv om han ikke konkretiserte det i slik grad at det fikk betydning for hans konklusjoner om «Retten til jorden i Finnmark». Om man likevel skulle være i tvil, bør utsagnet fra amtmannen i Finnmark i 1803 om at «Udskifting i senere Tiid er meget attraaet og udført ved Sorenskriver og Mænd» sette tvilen til side.

Forutsatt at 1775-resolusjonen initierte utskifting, som det etter gjennomgangen ovenfor er liten grunn til å betvile, må det også legges til grunn at bygdejorda langs fjordene i Finnmark, med andre ord engslettene og den nære utmarka, lå i jordfellesskap mellom oppsitterne, og ikke var i Kongens eie. Dette fordi utskifting uten private eiendommer ikke gir mening.

Merkes kan også at amtmannens uttalelse fra 1803 om at forholdene var de samme i Finnmark som i Nordlands amt, hvor mer en halvpartene av brukene lå i jordfellesskap ennå i $1859 .{ }^{122}$ For øvrig bekrefter også Jens Kraft at landet i Finnmark var «et Staten tilhørende Sameie», hvor henvisningen til

\footnotetext{
121 Finnmarkskommisjonens leder, Hilmar Meincke Krohg, hadde vært amtmann i Finnmark fra 1807 til 1811.

122 Langnes (2019) s. 281. 
staten må peke på jurisdiksjon eller høyhetsrett. Vi har også sett at det ennå på 1900-tallet kan ha eksistert jordfellesskap og eiendommer som neppe hadde sitt grunnlag i statlig jorddeling. Dessuten viser kirkebok for Vadsø sokneprestembete at det eksisterte eiendommer i eneeie i Varanger før offentlig utskifting eller jordinndeling hadde funnet sted.

Det må også tas med at man lett trår feil om man ser på den lagdelte eiendomsretten i den dansknorske enevoldstiden, og vurderer den ut fra dagens begreper og det rettsvern eiendom i dag har gjennom Grunnloven, Den europeiske menneskerettighetskonvensjonen og nasjonal ekspropriasjonslovgivning. Til det er både kongelig myndighet, rettsoppfatninger og terminologi for forskjellig. Synspunkter i litteratur og praksis etter 1850-tallet må for øvrig også vurderes i lys av den fornorskning og kulturrangering som da fikk plass i norsk politikk og rettslig tankegang.

Etter dette må det med stor sikkerhet kunne slås fast at bygde- eller siidajorda i Finnmark, som innbefattet betydelige utmarksstrekninger, ikke var Kongens eiendom på 1700-tallet i privatrettslig forstand. For allmenningene, de mer fjerntliggende utmarksstrekningene, er det ikke unaturlig [259] at Kongen anså seg som eier i medhold av hans høyhetsrett, på samme måte som han gjorde andre steder i landet.

Man skal være forsiktige med å si at eiendomsforholdene var de samme i Finnmarksbygdene som på Nordlandskysten og Vestlandet på 1700-tallet. Til det var nok de kulturelle og næringsmessige forskjellene for store, samtidig som kongemakt og proprietærer ikke hadde satt sine varige eiendomsmerker gjennom skyldsetting, etablering av leilendingssystemer og matrikulering av faste eiendommer, lengst nord i landet. Det kan også være at forskjellene lå langs tidsaksen; den samiske siidaordningen var ennå dominerende i betydelige deler av Finnmark på 1700-tallet, omtrent som slektene i middelalderen hadde rådet over gård og grunn i bygdene lenger sør. ${ }^{123}$ At jorda ikke var matrikulert, innebar likefullt at den var i noens eie.

Forskjellene tatt i betraktning, så er det langt mer sannsynlig at jordforholdene i Finnmark hadde større likheter med de langs Nordlandskysten, enn at jorda i Finnmark skulle ha hørt kongen til siden middelalderen. Om statens «eiendomsovertakelse» i 1863 er et resultat av at man knappe 50 år etter enevoldstidens opphør, hadde glemt dens lagdelte eiendomsbegrep, eller om det var aktverdige årsaker til den, tillater ikke plassen at det gås inn på her. Mye kan dog tyde på at eiendomsovertakelsen ikke skjedde med nødvendig aktsom god tro og at den således neppe bør ha vesentlig rettsvirkning i dag.

Til sist kan det anføres at Kongen eller staten har forestått utskifting og jorddeling mange steder; både i Danmark og lenger sør i Norge, uten at det har ledet til en oppfatning om at Kongen er blitt eier av jorda eller det gjenværende jordfellesskap. Det burde heller ikke være tilfellet i Finnmark. 


\section{Referanser}

\section{Litteratur}

Bjerkli, Bjørn, «Samisk befolkning, bruk av naturen og rettighetsforhold i Nord-Troms», NOU 2007:

14 Samisk naturbruk og rettssituasjon fra Hedmark til Troms s. 371-410.

Bing, Lars Hess, Beskrivelse over Kongeriget Norge, Øerne Island og Farøerne, samt Grønland, Kiøbenhavn 1796. [260]

Borgedal, Paul, «Jordeiendommenes historie i Norge» i Torleif Grendahl (red.), Jordskifteverket gjennom 100 år 1859-1958, Oslo 1959.

Brandt, Fr., Tingsretten fremstillet efter den norske Lovgivning, Christiania 1867.

Brenna, Wenche, «Samene i Norge: fornorskning og identitetsbygging», NOU 2016: 18 Hjertespråket s. $50-69$.

Brækhus, Sjur og Axel Hæren, Norsk tingsrett, Oslo 1964.

Bull, Kirsti Strøm, Jordsalgslovgivning. En rettshistorisk gjennomgang lovgjennomgang av jordsalgslovgivningen i Finnmark i perioden 1775-1965, 2014 (upubl.).

Eriksen, Gunnar, «Norsk tingsrett i Sapmi - en uting», Retfeerd 1995 s. 66-86.

Eriksen, Knut Einar og Einar Niemi, Den finske fare: sikkerhetsproblemer og minoritetspolitikk i nord 1860-1940, Oslo 1981

Geffroy, A., Sverig og Rusland i det 19. Aarhundre, Kjøbenhavn 1865.

Grenersen, Geir, «Finnefondet: et fornorskningsinstrument eller et ekstra lønnstillegg? En gjennomgang av fondets midler til lærerne 1901-1902» Historisk Tidsskrift 2015 s. 609-633.

Haffner, Vilhelm, Innstillinger og betenkninger fra kongelige og parlamentariske kommisjoner, departementale komiteer m.m. 1814-1924, Oslo 1925.

Hansen Lars Ivar og Bjørnar Olsen, Samenes historie fram til 1750, Oslo 2004.

Hardin, Garrett «The Tragedy of the Commons», Science 1968 s. 1243-1248.

Holm, Edvard, Danmark-Norges historie fra Den Store Nordiske Krigs Slutning til Rigernes Adskillelse (1790-1814), sjette bind, anden del, Kjøbenhavn 1909.

Jebens, Otto, Om eiendomsretten til grunnen i Indre Finnmark, Oslo 1999.

Juvkam, O., «Træk fra utskifningsvæsenets historie», Tidsskrift for Det norske Utdskiftningsvcesen, 1917 s. 41-161.

Juvkam, O., «Utstykking og skyldsetting i Finnmark», Tidsskrift for Det norske Utskiftingsvesen, 1948 s. $127-141$.

Kraft, Jens, Topografisk-Statistisk Beskrivelse over Kongeriget Norge, Sjette Deel, Det Nordenfjeldske Norge, Anden Deel, Christiania 1835.

Langnes, Mads, «Det fordervelege jordfellesskapet», Heimen 2019 s. 279-295, DOI: https://doi.org/10.18261/issn.1894-3195-2019-04-04. 
Meinich Olsen, K., Norsk almenningsret, Oslo 1928.

Michalsen, Dag, Rett en internasjonal historie, Oslo 2011 s. 242.

Niemi, Einar, Lokalbefolkningen og staten i Nesseby. Et utsyn fra 1700-tallet, 2017 (upubl).

Oskal, Nils, «Det moralske grunnlaget for diskvalifiseringen av urfolks eiendomsrett til land og politisk suverenitet», NOU 2001:34 s. 256-265.

Paus, Hans, Sorenskriver Hans Paus'Indberetning av 1769 om Finmarkens økonomisketilstand, Vadsø 1908. [261]

Pedersen, Steinar «Fra bruk av naturgodene etter samisk sedvaner til forbud mot salg til ikkenorsktalende», NOU 2001:34 Samiske sedvaner og rettsoppfatninger s. 291-381.

Rathke, Jens, Afhandling om de norske fiskerier og beretninger om reiser i aarene 1795-1802 for at studere fiskeriforhold m.v., Bergen 1907.

Ravna, Øyvind, «Jordutvisning og jordordning i Finnmark i et historisk perspektiv - med fokus på opprettelsen av jordskiftedomstolen», Kart og plan 1999 s. 132-145.

Ravna, Øyvind (red.), Jordskifterettene i Hålogaland. Historikk, jurisdiksjon og saklig kompetanse, Vadsø 2003.

Ravna, Øyvind, «Utmarkskommisjonen for Nordland og Troms og de samiske interessene», NOU 2007: 14 Samisk naturbruk og rettssituasjon fra Hedmark til Troms s. 607-726.

Ravna, Øyvind, «Nye bidrag til eiendomshistorien i Finnmark», Heimen 2017 s. 6-27, DOI: 10.18261/ISSN.1894-3195-2017-01-02.

Robberstad, Knut, «Kløyvd eiendomsrett», Lov og rett 1963 s. 162-166.

Sandvik, Gudmund, «Ei forelda lære: 'Statens umatrikulerte grunn i Finnmark'», Lov og Rett $1980 \mathrm{~s}$. 112-Sandvik, Gudmund «Europeisk rettshistorie i mellomalderen. Førelesningar», Jussens venner, 1989.

Sandvik, Gudmund, «Statens grunn i Finnmark. Et historisk perspektiv» i NOU 1993: 34 s. 334-380.

Sandvik, Gudmund, «Om oppfatningar av retten til og bruken av land og vatn i Finnmark fram mot slutten av 1960-åra», vedlegg til NOU 1997: 4 Naturgrunnlaget for samisk kultur s. 578-607.

Scheel, Herman, Forelcesninger over norsk Tingsret, Kristiania 1912.

Schlegel, Joh. Fredrik Wilhelm, Statistisk Beskrivelse af de fornemste europceiske Stater, Første Deel, Kiøbenhavn 1793.

Schnitler, Peter, Major Peter Schnitlers grenseeksaminasjonsprotokoller 1742- 1745, bind 3 ved Lars Ivar Hansen og Tom Schmidt, Norsk historisk kjeldeskrift-institutt, Oslo 1985.

Schiefloe, Asm., Hovedlinjer I Norsk almenningsrett, Oslo 1955.

Schou, Jacob Henric, Chronologisk Register over de Kongelige Forordninger og Aabne Breve, som fra Aar 1670 af ere udkomne, VII Deel, fra 1778 til 1780, Kiøbenhavn 1795.

Schou, Jacob Henric, Chronologisk Register over de Kongelige Forordninger og Aabne Breve, som fra Aar 1670 af ere udkomne, VIII Deel, fra 1781 til 1784, Kiøbenhavn 1795. 
Sommerfelt, Ole H., «Kort Beskrivelse over Finmarken», Topografisk Journal for Norge, bind 7, 1799. [262]

Spilling, Knut, «Utskiftingsvæsenet og jordforholdene i Finmarken», Tidsskrift for Det norske Utdskiftningsvoesen, 1920(a) s. 69-82.

Spilling, Knut, Av Finmarkens skogret, Bilag til Norsk Retstidende no. 4-6, Kristiania 1920(b).

Spilling, Knut, Om jordforhold og odelsrett i Finnmark, Oslo 1937

Steinsholt, Håvard, «Oreigning», Hans Sevatdal, ved Per Kåre Sky og Erling Berge (red.), Eigedomshistorie. Hovudliner i norsk eigedomshistorie frå 1600-talet fram mot nåtida, Oslo 2017 s. $376-382$.

Stenseth, Geir, Almenningens janusansikt. En sammenlignende rettslig analyse av almennings- og sameieforhold i norsk utmark, Oslo 2005. Sunde, Jørn Øyrehagen «På sporet av det tapte overbygslingsinstituttet», Historisk tidsskrift 2004 s. 181-205.

Thorsnæs, Geir, «Finmarkens amt», Store norske leksikon, 2017, https://snl.no/Finmarkens_amt (23.02.2020).

Tønnesen, Sverre, Retten til jorden i Finnmark. Rettsreglene om den såkalte «Statens umatrikulerte grunn» - en undersøkelse med sarlig sikte på samenes rettigheter, Bergen 1972.

Wessel-Berg, Fr. Aug., Kongelige Rescripter, Resolutioner og Collegial-Breve for Norge $i$ Tidsrummet 1660-1813, Andet Bind 1746-1780, Christiania 1842.

Wulff, Geir, «Seljemark Søndre, Ságat, 26.01.1994 s. 9.

Østberg, Kristian, Norsk bonderett, bind 11, fellesskap i jord og skog, Oslo 1936.

Aarhus universitet, «Rentekammeret», https://danmarkshistorien.dk (07.12.19).

\section{Lover, forarbeider, utredninger og andre offentlige dokumenter}

Fieldsted, Torkil, Extract Af Extract Af de Puncter i afgangne Sorenskriver Pauses Forslag i Finmarken betreffende, hvorover i Anledning af Jord-Inddeelingen udbedes Hr. Amtmand Fieldsteds Betænkning, i Statsarkivet i Tromsø, Arkivet etter Amtmannen/Fylkesmannen i Finnmark, SATØ/S-1120/1Afe/L1513 (udatert) (Transkribert av Y. Nedrebø, Arkivverket, seksjon for skriftforvaltning, 21.04.20).

Fieldsted, Torkil, promemoria 31.03.1775, i Riksarkivet/EA-3111 Rentekammeret, Kammerkanselliet, serie Gfd - Dokumenter til forestillinger, pakke 22 (1772-1775), mappe: N. res. 24/1775 (8/6), 1775 nr. 24, Finnmark vedk.

Finnmarkskommisjonen, Rapport felt 2 Nesseby, 2012.

Finnmarkskommisjonen, Rapport felt 6 Varanger vest, 2015.

Finnmarkskommisjonen, Rapport felt 4 Karasjok, bind 1, 2019.

Forestilling no. 24, Riksarkivet, Rentekammeret, Kammerkanselliet, G/Gf/Gfa/L0057: Norsk relasjons- og resolusjonsprotokoll (merket RK 52.57), 1775, https://media.digitalarkivet.no/view/60313/106 (15.12.19) (transkribert av Geir Wulff 07.12.19). 
Forhandlings Protocol Commissionen der er nedsatt for at foretage Undersøkelser om Midlerne til Finmarkens Opkomst 1826, http://xml.arkivverket.no/diverse/forhandprotfinnmarkkomm1824$\underline{\text { 30.pdf }}(15.12 .19)$. [263]

Forordning 20. august 1778 om Den Finmarkske Taxt og Handel.

Forordning 23 April 1781 om Jord-Fælledsskabets Ophævelse med flere foranstaltninger til Landvæsenets Forbedring i Danmark, (R.Kammer p. 230).

Forslag til landmålerinstruks, Tønnesen (1972) s. 392-397 med referanse kgl. Resolusjoner, nr. 12, 8. juni 1775, Rentekammeret, 1. Nordenfjeldske kontor 1775-77.

Innstilling om lov og forskrifter om Statens umatrikulerte grunn i Finnmark fylke, 1962 Hålogaland lagmannsrett, dom 28. jan. 1950 (sak 8-11/1950), Statsarkivet i Tromsø/ SATØ/S0066/F/Fa/Fac/L0068.

Kirkebok for Vadsø sogneprestembete (1764-1821), transkribert: http://www.rhd.uit.no/kirkebok/kbliste.aspx?kb=v\&rr=47339 (10.12.2019).

Kong Christian Den Femtis Norske Lov (NL) av 15. april 1687.

Kongelig Resolution 27. mai 1775 ang. Jorddelingen i Finmarken samt Bopladses Udvisning og Skyldlægning sammesteds, https://lovdata.no/dokument/NL/lov/1775-05-27 (15.12.19).

Lov 17. August 1821 angaaende Jord og Skovs Udskiftning av Fællesskab.

Lov 12. oktober 1857 om Udskiftning av Jord og Skovs Fællesskab

Lov 13. mars 1882 om utskiftning.

Lov 22. desember 1950 om jordskifte o.a.

Lov 17. juni 2005 nr. 85 om rettsforhold og forvaltning av grunn og naturressurser i Finnmark fylke (Finnmarksloven).

Norges Høyesterett: Rt. 1979 s. 492 (Varfjell-Stifjell), Rt. 2001 s. 1229 (Svartskogen), HR-2016-2030 (Stjernøya) og HR-2018-456-P (Nesseby).

NOU 1993: 34 Rett til og forvaltning av land og vann i Finnmark

Nytt juridisk arkiv avd. 1 (NJA) 1981

Oth. Prp. No. 21 (1848) Angaaende naadigst Proposition til Norges Riges Storthing om Udfærdigelse af en Lov om Ophævelse af $\S 38$ i Lov af 20de August 1821 om det beneficerede og Statens Gods.

Ot.prp. nr. 53 (2002-2003) Om lov om rettsforhold og forvaltning av grunn og naturressurser i Finnmark fylke (Finnmarksloven).

Pantebok nr. 1 (1776-1794), i Statsarkivet i Tromsø/SATØ, Sorenskriveren i Finnmark, $\mathrm{G} / \mathrm{Gb} / \mathrm{L} 0001 \mathrm{pb}$ : https://media.digitalarkivet.no/view/17338 (24.02.2020).

Registeringssentralen for historiske data (RHD), vielser i Vadsø prestegjeld fra 1779 til 1790, UiT, Tromsø.

Utkast til inndelings- og utskiftningslov for Finnmark, 25.11.1826, i Riksarkivet/EA-4036 Utenriksarkivet, serie $\mathrm{H}$ - Arnold Ræstads samlinger av diplomatisk materiale om grenseforhandlinger, underserie $\mathrm{Hb}$, eske 18: Kommisjonen til Finmarkens oppkomst. 